\title{
$\alpha 7$ Neuronal Nicotinic Acetylcholine Receptors Are Negatively Regulated by Tyrosine Phosphorylation and Src-Family Kinases
}

\author{
Eric Charpantier, ${ }^{2 *}$ Andreas Wiesner, ${ }^{1 *}$ Kyung-Hye Huh, ${ }^{1 *}$ Roch Ogier, ${ }^{2}$ Jean-Charles Hoda, ${ }^{2}$ Geraldine Allaman, ${ }^{2}$ \\ Mario Raggenbass, ${ }^{2}$ Dominik Feuerbach, ${ }^{3}$ Daniel Bertrand, ${ }^{2}$ and Christian Fuhrer ${ }^{1}$ \\ ${ }^{1}$ Department of Neurochemistry, Brain Research Institute, University of Zürich, CH-8057 Zürich, Switzerland, ${ }^{2}$ Department of Neurosciences, University \\ Medical Center, CH-1211 Geneva 4, Switzerland, and ${ }^{3}$ Novartis Institutes for BioMedical Research, CH-4002 Basel, Switzerland
}

\begin{abstract}
Nicotine, a component of tobacco, is highly addictive but possesses beneficial properties such as cognitive improvements and memory maintenance. Involved in these processes is the neuronal nicotinic acetylcholine receptor (nAChR) $\alpha 7$, whose activation triggers depolarization, intracellular signaling cascades, and synaptic plasticity underlying addiction and cognition. It is therefore important to investigate intracellular mechanisms by which a cell regulates $\alpha 7 \mathrm{nAChR}$ activity. We have examined the role of phosphorylation by combining molecular biology, biochemistry, and electrophysiology in SH-SY5Y neuroblastoma cells, Xenopus oocytes, rat hippocampal interneurons, and neurons from the supraoptic nucleus, and we found tyrosine phosphorylation of $\alpha 7$ nAChRs. Tyrosine kinase inhibition by genistein decreased $\alpha 7 \mathrm{nAChR}$ phosphorylation but strongly increased acetylcholine-evoked currents, whereas tyrosine phosphatase inhibition by pervanadate produced opposite effects. Src-family kinases (SFKs) directly interacted with the cytoplasmic loop of $\alpha 7 \mathrm{nAChRs}$ and phosphorylated the receptors at the plasma membrane. SFK inhibition by PP2 [4-amino-5-(4-chlorophenyl)-7-( $t$ butyl)pyrazolo[3,4- $d$ ]pyrimidine] or SU6656 (2,3-dihydro- $N, N$-dimethyl-2-oxo-3-[(4,5,6,7-tetrahydro- $1 H$-indol-2-yl)methylene]-1Hindole-5-sulfonamide) increased $\alpha 7 \mathrm{nAChR}$-mediated responses, whereas expression of active Src reduced $\alpha 7 \mathrm{nAChR}$ activity. Mutant $\alpha 7 \mathrm{nAChRs} \mathrm{lacking} \mathrm{cytoplasmic} \mathrm{loop} \mathrm{tyrosine} \mathrm{residues} \mathrm{because} \mathrm{of} \mathrm{alanine} \mathrm{replacement} \mathrm{of} \mathrm{Tyr-386} \mathrm{and} \mathrm{Tyr-442} \mathrm{were} \mathrm{more} \mathrm{active} \mathrm{than}$ wild-type receptors and insensitive to kinase or phosphatase inhibition. Because the amount of surface $\alpha 7$ receptors was not affected by kinase or phosphatase inhibitors, these data show that functional properties of $\alpha 7 \mathrm{nAChRs}$ depend on the tyrosine phosphorylation status of the receptor and are the result of a balance between SFKs and tyrosine phosphatases. These findings reveal novel regulatory mechanisms that may help to understand nicotinic receptor-dependent plasticity, addiction, and pathology.
\end{abstract}

Key words: nicotinic receptor; $\alpha 7$ nAChR; Src kinase; phosphorylation; phosphatase; regulation

\section{Introduction}

Protein phosphorylation and dephosphorylation are key mechanisms to regulate the activity of integral membrane proteins such as ion channels. In brain, tyrosine phosphorylation directs synaptic plasticity, as illustrated by the role of Src-family kinases (SFKs) in hippocampal long-term potentiation (LTP) and spatial learning (Grant et al., 1992; Lu et al., 1998). Although such LTP involves phosphorylation of glutamate receptors (Lu et al., 1998), the hippocampus and other brain areas are rich in other ligandgated channels such as neuronal nicotinic acetylcholine receptors (nAChRs) (Jones et al., 1999). However, regulatory mechanisms

Received March 10, 2005; accepted Sept. 15, 2005.

This work was supported by the Dr. Eric Slack-Gyr Foundation and by grants from the Swiss National Science Foundation (C.F., M.R., D.B.). We are grateful to Sonia Bertrand for her help with the oocyte experiments and to Roland Schoeb for help with photography.

*E.C., A.W., and K.-H.H. contributed equally to this work.

Correspondence should be addressed to Dr. Christian Fuhrer, Brain Research Institute, University of Zürich, Winterthurerstrasse 190, CH-8057 Zürich, Switzerland. E-mail: chfuhrer@hifo.unizh.ch. DOI:10.1523/JNEUROSCI.3497-05.2005

Copyright $\odot 2005$ Society for Neuroscience $\quad$ 0270-6474/05/259836-14\$15.00/0 of these brain nAChRs such as phosphorylation are still essentially unknown.

One of the most prominent nAChRs is the homomeric $\alpha 7$ receptor, which acts in synaptic plasticity underlying cognitive processing and addiction (Dajas-Bailador and Wonnacott, 2004). In hippocampus, $\alpha 7$ nAChRs are highly expressed in GABAergic interneurons in which they mediate cholinergic synaptic input (Alkondon et al., 1998; Frazier et al., 1998b) and regulate inhibition within the hippocampal network (Alkondon et al., 1997; Jones and Yakel, 1997). Activation of these $\alpha 7$ nAChRs blocks concurrent short-term potentiation and LTP induction in the pyramidal cells innervated by the interneurons (Ji et al., 2001). Inhibition of pyramidal neurons by postsynaptic $\alpha 7$ nAChRs on interneurons also underlies hippocampal auditory gating (Martin et al., 2004). Nicotine-activated presynaptic $\alpha 7$ receptors, because of their high calcium permeability, increase glutamate release in the ventral tegmental area, leading to LTP in dopaminergic neurons, a model for nicotine addiction (Mansvelder and McGehee, 2000)

$\alpha 7$ nAChRs are linked to many normal and pathological conditions. They are important in working memory formation, 
arousal, and attention (Levin, 2002), nicotine addiction, and nicotine-induced reversal of age-related memory deficits (Picciotto and Zoli, 2002). Their role in hippocampal auditory gating has linked the receptors to schizophrenia (Jones et al., 1999; Martin et al., 2004). The observation that $\alpha 7 \mathrm{nAChR}$ activation leads to neuroprotection against $\mathrm{A} \beta$-induced neurotoxicity (Kihara et al., 2001; Shaw et al., 2002), together with many other findings (Liu et al., 2001; Picciotto and Zoli, 2002), suggests that the receptor may play a key role in Alzheimer's disease.

These diverse physiological roles of $\alpha 7 \mathrm{nAChRs}$ are thought to reflect local calcium signaling that triggers downstream pathways, such as activation of cAMP response element-binding protein, protein kinase $\mathrm{A}$, and extracellular signal-regulated kinase 1/2 (Dajas-Bailador et al., 2002; Hu et al., 2002), or phosphatidylinositol 3-kinase, Akt, and Bcl-2 (Kihara et al., 2001). Such mechanisms result in expression of genes important in synaptic plasticity or cell survival (Berg and Conroy, 2002; Dajas-Bailador and Wonnacott, 2004). However, no signaling, scaffolding, or anchoring proteins that directly interact with $\alpha 7$ receptors have as yet been identified (Huh and Fuhrer, 2002).

We began addressing how phosphorylation and intracellular proteins regulate $\alpha 7 \mathrm{nAChRs}$. Our results reveal that a balance between kinases and phosphatases regulates tyrosine phosphorylation of the receptors at the cell surface. SFKs are part of these kinases, because SFKs bind and phosphorylate $\alpha 7$ receptors and regulate their activity. Interestingly, dephosphorylated $\alpha 7$ nAChRs cause increased ACh-evoked current, whereas phosphorylated receptors are less active, showing that tyrosine phosphorylation and SFKs negatively regulate receptor activity.

\section{Materials and Methods}

Culture of SH-SY5Y $\alpha 7$ cells and isolation of $\alpha$-bungarotoxin-binding (total) $\alpha 7$ receptors. SH-SY5Y neuroblastoma cells that were stably transfected with human $\alpha 7$ subunits (SH- $\alpha 7$ ) were maintained in DMEM/ Ham's F-12 (1:1) media containing 10\% fetal calf serum and $100 \mu \mathrm{g} / \mathrm{ml}$ G418 and were split every 3-4 d. Isolation of $\alpha$-bungarotoxin ( $\alpha$-BT)binding $\alpha 7$ receptors was done as described previously for muscle nAChRs from myotubes (Fuhrer and Hall, 1996; Mittaud et al., 2001). Briefly, SH- $\alpha 7$ cells were extracted in lysis buffer containing $1 \% \mathrm{NP}-40$, $30 \mathrm{~mm}$ triethanolamine, $50 \mathrm{~mm} \mathrm{NaCl}, 5 \mathrm{~mm}$ EDTA, 5 mм EGTA, $50 \mathrm{~mm}$ $\mathrm{NaF}, 2 \mathrm{~mm}$ Na-orthovanadate, $1 \mathrm{~mm}$ N-ethylmaleimide, $1 \mathrm{~mm} \mathrm{Na}$ tetrathionate, $50 \mu \mathrm{M}$ phenylarsine-oxide, $10 \mathrm{~mm} p$-nitrophenylphosphate, $25 \mu \mathrm{g} / \mathrm{ml}$ aprotinin, $25 \mu \mathrm{g} / \mathrm{ml}$ leupeptin, $2 \mathrm{~mm} \mathrm{Na}$-orthovanadate, and $1 \mathrm{~mm}$ PMSF. Cell lysates were cleared by centrifugation (refrigerated Eppendorf centrifuge, $14,000 \mathrm{rpm}, 5 \mathrm{~min}$ at $4^{\circ} \mathrm{C}$; Eppendorf Scientific, Westbury, NY), and supernatants were incubated with $200 \mathrm{~nm}$ biotinylated $\alpha$-BT (Invitrogen, Eugene, OR). Streptavidin-agarose beads (Invitrogen) were added to precipitate $\alpha 7 \mathrm{nAChRs}$. Nonspecific binding was determined by applying $10 \mu \mathrm{M}$ free (nonbiotinylated) $\alpha$-BT before addition of biotinylated $\alpha$-BT. After precipitation, bead pellets were washed, and bound proteins were eluted and subjected to SDS-PAGE and Western blot analysis. $\alpha 7$ receptors were detected using goat polyclonal antibodies raised against the $\alpha 7 \mathrm{C}$ terminus (1:200 dilution; Santa Cruz Biotechnology, Santa Cruz, CA) (Drisdel and Green, 2000) or rabbit polyclonal antibodies raised against the $\alpha 7 \mathrm{~N}$ terminus (1:1000 dilution; Abcam, Cambridge, UK). Both antibodies gave the same results. $\alpha 7$ receptors isolated in this manner reflect the total cellular pool of $\alpha 7$ $\mathrm{nAChRs}$. In our figures, $\alpha$-BT-precipitations (Tox-P) represent such total $\alpha 7$ receptor isolations, unless specified as surface or intracellular precipitation (see below).

Isolation of surface and intracellular $\alpha 7 n A$ ChRs. To precipitate $\alpha 7$ receptors from the surface of $\mathrm{SH}-\alpha 7$ cells, we used a protocol established previously for muscle nAChRs in myotubes (Moransard et al., 2003). Briefly, intact SH- $\alpha 7$ cells were incubated in media with 200 nм biotinylated $\alpha$-BT for $45 \mathrm{~min}$ in the culture incubator. Nonspecific binding was determined by applying $10 \mu \mathrm{M}$ free (nonbiotinylated) $\alpha$-BT $30-45 \mathrm{~min}$ before adding biotinylated $\alpha$-BT. Cells were washed twice with PBS and lysed as described above. Streptavidin-agarose beads were added to precipitate surface AChRs.

Intracellular $\alpha 7$ receptors were precipitated as described previously for muscle nAChRs (Moransard et al., 2003). Briefly, intact SH- $\alpha 7$ cells were preincubated for $45 \mathrm{~min}$ with $1 \mu \mathrm{M}$ free $\alpha$-BT in media in the culture incubator to block surface receptors. Cells were washed twice with PBS to remove unbound $\alpha$-BT and lysed. Biotinylated $\alpha$-BT (200 nM) was added to lysates, followed by streptavidin-agarose beads, to isolate intracellular $\alpha 7$ nAChRs.

In these preparations, surface and intracellular $\alpha 7$ receptors were additive to yield total receptors (K. H. Huh and C. Fuhrer, unpublished observations).

Treatment of $\mathrm{SH}-\alpha 7$ cells with pervanadate and kinase inhibitors. Pervanadate was prepared as described previously (Meier et al., 1995) and used at a standard concentration of $50 \mu \mathrm{M}$ in culture medium on SH- $\alpha 7$ cells for $20 \mathrm{~min}$ before lysis. To block tyrosine kinases, cells were pretreated with genistein (100 or $250 \mu \mathrm{M}$ for $10 \mathrm{~min})$, PP2 [4-amino-5-(4chlorophenyl)-7-( $t$-butyl)pyrazolo[3,4-d]pyrimidine] (1 or $10 \mu \mathrm{M}$ for 10 min (Smith et al., 2001), CGP77675; [10 $\mu \mathrm{M}$ for 45-90 min (Missbach et al., 1999)], or 2,3-dihydro- $N, N$-dimethyl-2-oxo-3-[(4,5,6,7-tetrahydro$1 H$-indol-2-yl)methylene]- $1 H$-indole-5-sulfonamide [SU6656; a substituted 5,7-diphenyl-pyrrolo[2,3-d]pyrimidine [10 $\mu \mathrm{M}$ for $30 \mathrm{~min}$ (Blake et al., 2000)] before addition of pervanadate ( $50 \mu \mathrm{M}$ for $20 \mathrm{~min}$ ). After these treatments, cells were lysed, and $\alpha 7$ receptors were precipitated as described above. Tyrosine phosphorylation of $\alpha 7$ receptors and SFK association were evaluated by Western blotting.

Preparation of rat brain membrane homogenates. Whole brains from postnatal day 5 (P5) rats or forebrains from P30 rats (Lewis) were homogenized in lysis buffer containing 1\% NP-40, DTT ( $2 \mu \mathrm{M})$, and pepstatin $(5 \mu \mathrm{g} / \mathrm{ml})$. Homogenized material was incubated at $4^{\circ} \mathrm{C}$ for $30 \mathrm{~min}$ for lysis and centrifuged at 55,000 rpm for $20 \mathrm{~min}$. Cleared soluble lysates were incubated with $\alpha$-BT directly coupled to Sepharose beads (Fuhrer and Hall, 1996) for $2 \mathrm{~h}$ to isolate $\alpha 7$ receptors. For determination of nonspecific binding, these lysates were preincubated with $10 \mu \mathrm{M}$ free $\alpha$-BT for 30 min before incubation with $\alpha$-BT-coupled beads. After incubation, beads were processed as described above. Phosphorylation of the receptors and association of SFKs were determined by Western blot analysis.

Additional antibodies and Western blot analysis. Tyrosine phosphorylation was detected using phosphotyrosine-specific antibodies (4G10; Upstate Biotechnology, Lake Placid, NY). Antibodies against Src-family kinases [pan-Src antibodies (Src-CT), Lyn and Fyn] and glutathione $S$-transferase (GST) were purchased from Santa Cruz Biotechnology (Fuhrer and Hall, 1996). Specific antibodies against Src were from Oncogene Sciences (Boston, MA) (Fuhrer and Hall, 1996). Blots were probed with antibodies in 4 G10 blocking solution ( $5 \%$ BSA, $0.5 \%$ NP-40 in TBST $(0.1 \%$ Tween-20, $20 \mathrm{~mm}$ Tris, $137 \mathrm{~mm} \mathrm{NaCl}, \mathrm{pH}$ 7.6)) or in 5\% milk in TBST. Proteins were detected by chemiluminescence using a kit from Amersham Biosciences (Little Chalfont, UK). For reprobing, blots were stripped by incubating them for $20 \mathrm{~min}$ in $200 \mathrm{~mm}$ glycine, $0.1 \%$ Tween 20 , pH 2.5 .

Determination of putative phosphorylation sites. The Netphos 2.0 software (Blom et al., 1999) (http://www.cbs.dtu.dk/services/NetPhos/) was used to determine putative phosphorylation sites in the $\alpha 7$ protein sequence. Tyrosines known to be phosphorylated in nAChR subunits from Torpedo californica (Wagner et al., 1991) were aligned with human $\alpha 7$ nAChRs to further analyze phosphorylation sites. Combination of software prediction and sequence alignment data, also using $\alpha 7$ sequences from a variety of species, was used to predict phosphorylation sites in human $\alpha 7$ receptors.

DNA constructs. Sequences encoding the cytoplasmic loop (amino acids 325-459; GST- $\alpha$ 7loop) or the C-terminal region including the fourth transmembrane domain (amino acids 461-502; GST- $\alpha 7$ TM4CT) of the human $\alpha 7$ receptor were inserted in frame into pGEX-2T vector encoding glutathione-S-transferase (GST). Tyrosines 386 or 442 in GST$\alpha 7$ loop were mutated to alanine using QuikChange site-directed mutagenesis kit (Stratagene, La Jolla, CA) to generate GST- $\alpha 7$ (A386), GST$\alpha 7$ (A442), and GST- $\alpha 7$ (A386/442). Fusion proteins were expressed in $\mathrm{DH} 5 \alpha$ bacterial strain and purified using glutathione-Sepharose beads as described previously (Fuhrer and Hall, 1996). Mutant $\alpha 72$ Y-A receptors 
were constructed accordingly, using QuikChange site-directed mutagenesis kit and the full-length human $\alpha 7$ sequence in a pcDNA3-based expression vector (TOPO vector). Expression vectors for viral $\mathrm{Src}(\mathrm{vSrc})$ and vSrc-KD (kinase-dead vSrc) were kindly provided by Dr. Todd Holmes (New York University, New York, NY) (Nitabach et al., 2001, 2002).

SFK association and in vitro phosphorylation of GST- $\alpha 7$ fusion proteins. To study interaction with SFKs (see Fig. $7 d$ ), purified glutathione-Sepharose bead-bound fusion proteins were added for $2 \mathrm{~h}$ to $\mathrm{SH}-\alpha 7$ lysates prepared as described above. After washing with high- and low-salt wash buffers (Fuhrer and Hall, 1996), the resulting precipitates were used to evaluate the association of SFKs by Src-CT Western blotting.

To examine tyrosine phosphorylation of fusion proteins by SFKs from $\mathrm{SH}-\alpha 7$ cells in vitro (see Fig. $8 c$ ), cells were pretreated with pervanadate alone or in combination with PP2. Lysates were incubated with purified GST- $\alpha$ 7loop fusion proteins, and beads were precipitated and washed. Beads were incubated in phosphorylation assay buffer containing $3 \mathrm{~mm}$ ATP (20 mm Tris, pH 7.4, 10 mm $\mathrm{MgCl}_{2}, 2 \mathrm{~mm} \mathrm{Na-orthovanadate,} \mathrm{and} 1$ mM PMSF) for $15 \mathrm{~min}$ at $37^{\circ} \mathrm{C}$ or $4^{\circ} \mathrm{C}$. Beads were centrifuged at $4^{\circ} \mathrm{C}$ to remove supernatant, and attached proteins were analyzed by SDS-PAGE and Western blot.

To examine tyrosine phosphorylation of fusion proteins by Src kinase in vitro (see Fig. $8 d$ ), purified GST- $\alpha$ 7loop(WT), GST- $\alpha$ 7(A386), GST$\alpha 7$ (A442), and GST- $\alpha 7$ (A386/442) proteins were incubated with $1.5 \mathrm{U}$ of purified human Src kinase (c-Src; Upstate Biotechnology). Incubations were performed in phosphorylation assay buffer containing $10 \mu \mathrm{M}$ ATP (20 mM HEPES, $10 \mathrm{~mm} \mathrm{MgCl}_{2}$, and $100 \mathrm{~mm} \mathrm{NaCl}$ ) as described above.

Labeling with Alexa $488-\alpha-B$ T and fluorescence microscopy. $\mathrm{SH}-\alpha 7$ cells were grown for $5 \mathrm{~d}$ on L-lysine- and laminin-coated plates in medium supplemented with $20 \mu \mathrm{M}$ all-trans-retinoic acid to promote neural differentiation. Medium was exchanged by media lacking fetal bovine serum, and $20 \mathrm{ng} / \mathrm{ml}$ BDNF was added for $5 \mathrm{~d}$. To stain cells, $100 \mathrm{~nm}$ Alexa 488 -coupled $\alpha$-BT (Molecular Probes) was added for $1 \mathrm{~h}$. Nonspecific binding was assessed by incubating cells in $10 \mu \mathrm{M}$ unlabeled $\alpha$-BT or 1 mM nicotine $10 \mathrm{~min}$ before and during the labeling with Alexa $488-\alpha-$ BT. Cells were washed in buffer containing $4^{\prime}, 6^{\prime}$-diamidino-2phenylindole (DAPI) to label nuclei, fixed with cryofix, and mounted on coverslips. Conventional fluorescence imaging was done using a Zeiss (Oberkochen, Germany) Axioskop 2 microscope equipped with a cooled Hamamatsu (Schüpfen, Switzerland) Orca digital camera, using $1000 \times$ magnification. Alexa $488-\alpha$-BT detected clusters on cell somata and processes, and this signal was abolished by unlabeled $\alpha$-BT or nicotine (data not shown), confirming that it corresponds to $\alpha 7$ receptors.

Oocyte preparation and cDNA injection. Xenopus oocytes were isolated and prepared as described previously (Eisele et al., 1993; Krause et al., 1998). Two nanograms of expression vectors containing the various cDNAs were injected into the oocyte nucleus. Each oocyte was injected with TOPO expression vector containing wild-type human $\alpha 7$ or mutant $\alpha 72 \mathrm{Y}$-A receptor DNA. For experiments with vSrc kinase, the ratio was 10:1 for $\alpha 7$ versus vSrc or vSrc-KD DNA. Oocytes were incubated for 2-3 $\mathrm{d}$ at $18^{\circ} \mathrm{C}$ in Barth's solution that contained $88 \mathrm{~mm} \mathrm{NaCl}, 1 \mathrm{~mm} \mathrm{KCl}, 2.4$ $\mathrm{mm} \mathrm{NaHCO}_{3}, 10 \mathrm{~mm}$ HEPES, $0.82 \mathrm{~mm} \mathrm{MgSO}_{4} \cdot 7 \mathrm{H}_{2} \mathrm{O}, 0.33 \mathrm{~mm}$ $\mathrm{Ca}\left(\mathrm{NO}_{3}\right)_{2} \cdot 4 \mathrm{H}_{2} \mathrm{O}$, and $0.41 \mathrm{~mm} \mathrm{CaCl} \cdot 6 \mathrm{H}_{2} \mathrm{O}$, at $\mathrm{pH}$ 7.4, supplemented with $20 \mu \mathrm{g} / \mathrm{ml}$ kanamycine, $100 \mathrm{U} / \mathrm{ml}$ penicillin, and $100 \mu \mathrm{g} / \mathrm{ml}$ streptomycin.

Binding assay with ${ }^{125} I-\alpha-B T$. Oocytes labeling experiments were performed $2 \mathrm{~d}$ after DNA injection. Oocytes were incubated for $1 \mathrm{~h}$ in either control solution or the presence of $10 \mu \mathrm{M}$ genistein, ${ }^{125} \mathrm{I}-\alpha$-BT (Amersham Biosciences, Arlington Heights, IL) was added at a final concentration of $10 \mathrm{~nm}$, and cells were incubated for $1 \mathrm{~h}$. After labeling, oocytes were individually washed five times in cold OR2 buffer (for buffer ingredients, see next paragraph). To prevent adsorption of the toxin on the plastic, all solutions were supplemented with $20 \mu \mathrm{g} / \mathrm{ml} \mathrm{BSA}$. Each oocyte was then placed in a vial, and the amount of radioactive ${ }^{125} \mathrm{I}-\alpha$-BT was determined using a gamma counter ( 2 min counting mode). Nonspecific binding was determined using $1 \mu \mathrm{M}$ unlabeled $\alpha$-BT ( $1 \mathrm{~h}$ preincubation and during radioactive labeling). Thirty oocytes were tested in each condition. Expression rates in oocytes are known to vary considerably (Yoshii et al., 1987; Yu et al., 1991; Cruz-Martin et al., 2001). For this reason, only cells displaying a labeling superior to nonspecific binding were used for the computation, and mean nonspecific values were subtracted. Using a ${ }^{125} \mathrm{I}-\alpha$-BT standard, the amount of bound toxin was calculated in femtomoles per oocyte.

To label SH- $\alpha 7$ cells, cells were grown on $35 \mathrm{~mm}$ dishes to a confluence of $60-100 \%$ and incubated with $10 \mathrm{nM}{ }^{125} \mathrm{I}-\alpha$-BT for $1 \mathrm{~h}$ in cell medium. Inhibitor treatments were as in the corresponding biochemical experiments (100 $\mu \mathrm{m}$ genistein was added for $30 \mathrm{~min}, 10 \mu \mathrm{M}$ PP2 for $90 \mathrm{~min}$, and $50 \mu \mathrm{M}$ pervanadate for $20 \mathrm{~min}$ before ${ }^{125} \mathrm{I}-\alpha$-BT), and inhibitors were present during the radioactive labeling. Nonspecific binding was determined by adding $1 \mu \mathrm{M}$ unlabeled toxin $1 \mathrm{~h}$ before and during radioactive labeling. Cells were then washed twice with ice-cold PBS and solubilized in lysis buffer as described above (paragraph about precipitation with biotin- $\alpha$-BT). Lysates were analyzed in a gamma counter, and aliquots were taken for protein determination assays. Radioactive signals were robust (30,000-100,000 cpm), the nonspecific background was low (5-10\%), and protein levels did not vary between individual cell lysates in an experiment. Cell treatments at $37^{\circ} \mathrm{C}$ or $21^{\circ} \mathrm{C}$ produced the same results.

Oocyte electrophysiological recordings. Cells were continuously superfused with OR2 that contained $82.5 \mathrm{~mm} \mathrm{NaCl}, 2.5 \mathrm{~mm} \mathrm{KCl}, 5 \mathrm{~mm}$ HEPES, $2.5 \mathrm{~mm} \mathrm{CaCl}_{2} \cdot 2 \mathrm{H}_{2} \mathrm{O}$, and $1 \mathrm{~mm} \mathrm{MgCl}_{2} \cdot 6 \mathrm{H}_{2} \mathrm{O}, \mathrm{pH} 7.4$, and $0.5 \mu \mathrm{M}$ atropine was added to prevent possible activation of endogenous muscarinic receptors. All drugs were diluted in the OR2 medium immediately before the experiment. Bovine serum albumin $(20 \mathrm{mg} / \mathrm{ml})$ was added to the perfusion and drug media to prevent adsorption of the compounds to the plastic. Electrophysiological recordings were performed using a twoelectrode voltage clamp (GENECLAMP amplifier; Axon Instruments, Forster City, CA), and cells were held at $-100 \mathrm{mV}$. The flow rate was $\sim 6$ $\mathrm{ml} / \mathrm{min}$, and the volume of the chamber was $<100 \mu \mathrm{l}$ to allow rapid solution exchange.

To minimize contamination by endogenous $\mathrm{Ca}^{2+}$-activated chloride channels, oocytes were incubated with BAPTA-AM $(100 \mu \mathrm{M})$ for at least $3 \mathrm{~h}$ before recording. For preincubation experiments, oocytes were incubated with drugs diluted in Barth's medium in the presence of BAPTA-AM $(100 \mu \mathrm{M})$. Preincubation periods of $1-2 \mathrm{~h}$ were used for genistein and inactive genistein and of 30-60 min for pervanadate. Recordings performed after preincubations were done in the presence of an identical drug concentration to prevent drug washout. To limit possible direct drug effect on the $\alpha 7$ receptor, the drug application was stopped $1 \mathrm{~s}$ before and restarted immediately after the acetylcholine test pulse.

For oocyte data analysis, dose-response curves were fit using the empirical Hill equation: $Y=1 / 1+\left(\mathrm{EC}_{50} / x\right) \hat{n}_{H}$, where $y$ is the fraction of remaining current, $\mathrm{EC}_{50}$ is the concentration of half-inhibition, $n_{H}$ is the apparent cooperativity, and $x$ is the agonist concentration.

Values indicated throughout the text are given with their respective SEM. For statistical analysis, we used the unpaired, two-tailed Student's $t$ test.

Genistein, inactive genistin (Igen), and sodium orthovanadate were purchased from Sigma (St. Louis, MO), and PP2, PP3 (4-amino-7phenylpyrazol[3,4-d]pyrimidine), and SU6656 were from Calbiochem (Juro, Lucern, Switzerland). Stock solutions of genistein and its inactive analog were made in DMSO and diluted to their final concentration in OR2. The maximal concentration of DMSO applied to oocytes was $1 \%$ $(\mathrm{v} / \mathrm{v})$, a concentration that had no effect on the oocyte resting membrane conductance or on the ACh-evoked responses. Pervanadate was prepared as described previously (Meier et al., 1995).

Electrophysiological recordings in $\mathrm{SH}-\alpha \mathrm{T}$ cells. Cells were maintained in culture using the same conditions as described for the biochemical experiments. Two to $4 \mathrm{~d}$ before the electrophysiological assays, cells were seeded into $35 \mathrm{~mm}$ dishes. Cells were washed three times with artificial CSF (in mu: $130 \mathrm{NaCl}, 5 \mathrm{KCl}, 2 \mathrm{CaCl}_{2}, 2 \mathrm{MgCl}_{2}$, and $10 \mathrm{HEPES}, \mathrm{pH}$ adjusted to 7.4 with $\mathrm{NaOH}$ ) and placed on the stage of an inverted Axiovert 100 microscope (Zeiss). Whole-cell recording patches were achieved using borosilicate tubes pulled with a BB-CH-PC (Mecanex, Nyon, Switzerland). Electrodes were filled with an intracellular solution (in mM: $130 \mathrm{~K}$-gluconate, $5 \mathrm{NaCl}, 2 \mathrm{MgCl}_{2}, 10$ HEPES, and 5 EGTA, pH adjusted to 7.4 with $\mathrm{KOH}$ ) and had a typical resistance of 2-3 $\mathrm{M} \Omega$. Currents were recorded using an AxoPatch 200B (Axon Instruments) 
digitized with a card PCI-1200 from National Instruments (Austin, TX), and data were stored on a Macintosh computer (Apple Computers, $\mathrm{Cu}$ pertino, CA), using MacDatac software. Drugs were applied using a theta tube mounted on a piezo quartz (Physiks Instruments, Walbronn Germany), as described previously (Buisson and Bertrand, 2001), that allowed very fast drug delivery. Solution exchanges were controlled by electromagnetic valves driven by the data acquisition system.

Preparation of brain slices. Two- to 5-week-old rats [Sprague Dawley; Charles River Wiga (Sulzfeld, Germany), Iffa Credo (L'Arbresle, France)] were anesthetized (pentobarbital, $50 \mathrm{mg} / \mathrm{kg}$, i.p.) and decapitated in accordance with the rules of the Swiss Federal Veterinary Office. The brain was rapidly removed, and coronal hypothalamic or transverse hippocampal slices, 300-400 $\mu \mathrm{m}$ thick, were prepared as described previously (Zaninetti et al., 2000; Ogier and Raggenbass, 2003). A single slice, containing either the supraoptic nucleus or the CA1 region of the hippocampus, was transferred to a thermoregulated recording chamber $\left(32-33^{\circ} \mathrm{C}\right)$, submerged and continuously perfused with a solution containing $135 \mathrm{~mm} \mathrm{NaCl}, 15 \mathrm{~mm} \mathrm{NaHCO}, 5 \mathrm{~mm} \mathrm{KCl}, 1 \mathrm{~mm} \mathrm{MgCl}_{2}, 2 \mathrm{~mm}$ $\mathrm{CaCl}_{2}$, and $10 \mathrm{~mm}$ glucose and saturated with a gas mixture composed of $95 \% \mathrm{O}_{2} / 5 \% \mathrm{CO}_{2}, \mathrm{pH} 7.3-7.4$. The perfusion solution was supplemented with $2 \mu \mathrm{M}$ atropine to prevent activation of muscarinic receptors. The recording chamber was set on the stage of an Eclipse E600FN (Nikon, Tokyo, Japan), equipped with a $40 \times, 0.8$ numerical aperture waterimmersion objective and differential interference contrast optics, and neurons were visualized using an infrared-sensitive video camera (C2400-07; Hamamatsu).

Whole-cell recordings in brain slices. Patch pipettes were pulled from borosilicate glass capillaries (Harvard Apparatus, Edenbridge, UK) and had tip resistances of 3-6 M 2 . The patch pipette solution contained the following (in $\mathrm{mM}$ ): $140 \mathrm{~K}$-gluconate, $10 \mathrm{KCl}, 10 \mathrm{HEPES}, 4 \mathrm{MgCl}_{2}, 0.1$ BAPTA, $2 \mathrm{Na}_{2}$-ATP, and $0.4 \mathrm{Na}_{2}$-GTP, pH 7.2-7.3. The osmolarity of the pipette solution was $285-310$ mOsm. Gigaohm seals were made by applying a slight negative pressure to the back of the pipette, and access to the whole-cell configuration was achieved by further applying negative pressure. Access resistance was 10-25 $\mathrm{M} \Omega$. Neurons were voltage clamped at $-70 \mathrm{mV}$, and current signals were amplified using an Axopatch $200 \mathrm{~A}$ (Axon Instruments). They were low-pass filtered at $2 \mathrm{kHz}$ and digitized at $5 \mathrm{kHz}$. ACh $(0.2-1 \mathrm{~mm})$ was applied by pressure ejection from patch-type pipette ( $30 \mathrm{psi}, 40-400 \mathrm{~ms}$ ) positioned within $10-20$ $\mu \mathrm{m}$ from the soma of the recorded neuron.

\section{Results}

\section{Tyrosine phosphorylation of $\alpha 7 \mathrm{nAChRs}$}

nAChRs can be divided in two main groups according to their sensitivity to $\alpha$-BT (Dani, 2001). The most abundant receptor subtype of the $\alpha$-BT-sensitive group is the $\alpha 7$ receptor, composed of five identical subunits (Berg and Conroy, 2002). To investigate whether $\alpha 7 \mathrm{nAChRs}$ are phosphorylated on tyrosine residues, we took advantage of SH-SY5Y cells, a human neuroblastoma cell line used for studying nicotinic receptors. The cells express low levels of functional $\alpha 7$ receptor channels, which specifically bind $\alpha$-BT (Peng et al., 1994; Puchacz et al., 1994; Groot Kormelink and Luyten, 1997). We stably transfected the cells with human $\alpha 7$ $\mathrm{nAChR}$ expression vector to create $\mathrm{SH}-\alpha 7$ cells, which showed abundant and saturable $\alpha$-BT binding. This was demonstrated by $\alpha 7$ receptor precipitation using biotin- $\alpha$-BT and streptavidinagarose, followed by $\alpha 7$ Western blot (Fig. 1) and by ${ }^{125} \mathrm{I}-\alpha$-BT binding (D. Feuerbach, unpublished observations). $\alpha 7 \mathrm{nAChRs}$ migrated as a major band of $\sim 50 \mathrm{kDa}$ (Fig. 1) and occasionally as an additional band of $\sim 55 \mathrm{kDa}$ (see Fig. 5), as observed previously in other cell lines and vertebrate brain (Drisdel and Green, 2000).

Treatment of SH- $\alpha 7$ cells with the tyrosine phosphatase inhibitor pervanadate for $20 \mathrm{~min}$ produced strong phosphorylation of $\alpha 7$ receptors (Fig. 1). Preincubation of cells with the general tyrosine kinase inhibitor genistein resulted in reduction of $\alpha 7$ phosphorylation in a dose-dependent way. These findings dem-

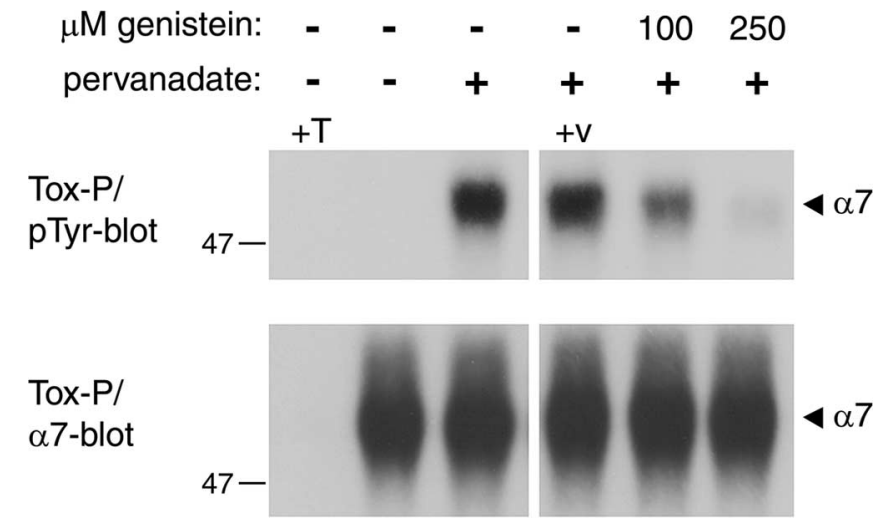

Figure 1. Regulation of $\alpha 7$ receptor tyrosine phosphorylation by genistein and pervanadate. SH- $\alpha 7$ cells were treated for 10 min with genistein, followed by addition of $50 \mu \mathrm{m}$ pervanadate for $20 \mathrm{~min}$ in the presence of genistein. In controls, these compounds were omitted or the vehicle alone $(0.25 \%$ DMSO, $+v)$ was added. Cells were lysed and $\alpha 7$ receptors were precipitated using biotinylated $\alpha-\mathrm{BT}$ and streptavidin-agarose (Tox-P). As a control, an excess of free $\alpha$-BT was added before precipitation $(+\mathrm{T})$. Immunoblotting using phosphotyrosinespecific antibodies, followed by $\alpha 7$ reprobing, reveals that pervanadate causes strong $\alpha 7$ receptor phosphorylation, which is greatly reduced by genistein. Shorter exposure times and side-by-side alignment of blots confirmed precise overlap between phosphotyrosine and $\alpha 7$ signals (data not shown).

onstrate, for the first time, tyrosine phosphorylation of $\alpha$-BTbinding $\alpha 7 \mathrm{nAChRs}$. This phosphorylation results from a balance between tyrosine kinase and phosphatase activity and can be increased by pervanadate and decreased by genistein. Interestingly, $\alpha 7 \mathrm{nAChR}$ phosphorylation is under dynamic regulation, with an apparent turnover time of $<20 \mathrm{~min}$.

\section{Inhibition of tyrosine kinases by genistein increases $\alpha 7$ nAChR responses}

Genistein modulates the activity of ligand-gated channels by both a direct and indirect action (Jassar et al., 1997; Huang et al., 1999; Balduzzi et al., 2002). Although direct effects are thought to arise from an interaction with the channel itself, indirect effects stem from inhibiting intracellular phosphorylation pathways. To examine whether genistein modulates $\alpha 7$ receptors and to distinguish between direct and indirect actions, two experimental protocols were designed and electrophysiological recordings were performed on Xenopus oocytes expressing human $\alpha 7$ nAChRs. First, we assayed the effect of coapplication of increasing genistein concentrations with a fixed ACh test pulse $(200 \mu \mathrm{M}, 2 \mathrm{~s})$. Under these circumstances, ACh-evoked currents were slightly increased by genistein, and the plateau phase was modified at high genistein concentration (Fig. 2a). This reflects direct genistein action on the $\alpha 7$ channel because it is very unlikely that modification of phosphorylation pathways occurs within the short ACh test pulse. Second, genistein was preapplied in increasing concentration for $1-2 \mathrm{~h}$, allowing it to interact with intracellular tyrosine kinases. To minimize contamination by genistein during the subsequent ACh test pulse, a brief gap of superfusion with control buffer was introduced ( 1 s; see Materials and Methods). Under these conditions, ACh-evoked currents were more strongly potentiated (Fig. $2 b$ ). We also tested shorter genistein preincubation times, from 10 to $60 \mathrm{~min}$, and found similar effects, albeit with a higher cell-to-cell variation (data not shown).

Plots of the peak of the ACh-evoked currents recorded with the two protocols as a function of the genistein concentrations are shown in Figure $2 c$. Genistein preapplication caused a stronger effect than coapplication. In preapplication, $\alpha 7$ receptor poten- 
tiation is independent of the presence of genistein during the ACh test pulse, indicating that most of this genistein effect (at least a threefold potentiation) results from inhibition of intracellular phosphorylation rather than direct action on the $\alpha 7$ channel. We thus used the preapplication protocol for all subsequent experiments. We noticed that the genistein effect is rapidly reversible. After extensively washing oocytes for $10 \mathrm{~min}$, new ACh test pulses evoked responses of normal amplitude and time course (data not shown). This suggests that phosphorylation occurs rapidly, consistent with the rapid turnover of $\alpha 7$ phosphorylation detected in our biochemical experiments in Figure 1.

Specificity of genistein was tested using the biologically inactive derivative Igen. Preapplication of Igen had no effect on ACh-evoked currents (Fig. 2d). ACh doseresponse curves revealed a significant increase in the ACh-evoked response attributable to genistein at almost all ACh concentrations, whereas Igen produced no effect (Fig. 2e). The $\mathrm{EC}_{50}$ of ACh was not significantly affected by genistein (supplemental Table 1, available at www. jneurosci.org as supplemental material).

To rule out the possibility that genistein potentiation of $\alpha 7$ responses is restricted to receptors expressed in Xenopus oocytes, electrophysiological experiments were conducted in $\mathrm{SH}-\alpha 7$ cells. These cells share several properties with neurons, have endogenous $\alpha 7$ receptors, and thus provide a native environment for $\alpha 7$ nAChRs. Fast agonist applications revealed that these cells display typical AChevoked currents and that brief exposure to genistein ( $1 \mathrm{~min}$ ) was sufficient to cause a significant increase of the ACh responses in 27 of the 35 cells tested (Fig. 3a). To avoid a direct effect of genistein, cells were washed for $5 \mathrm{~s}$ before the ACh pulse. The typical time course of the ACh-evoked current suggests that these responses indeed reflect activation of $\alpha 7$ receptors. This was confirmed by the full blockade of the currents after 3 min exposure to $100 \mathrm{~nm} \alpha$-BT (Fig. 3a). Pooled data showed that the genisteininduced increase in ACh current was on average 2.3-fold (Fig. 3c). Genistein exposure up to $3 \mathrm{~min}$ did not cause further potentiation ( $n=11$ trials; analyzed by paired Student's $t$ tests). Because of the nature of the cell patch for recording, longer genistein incubation times could not be tested.

To verify that native $\alpha 7 \mathrm{nAChRs}$ behave similarly to receptors in SH-SY5Y cells and receptors expressed in Xenopus oocytes, effects of genistein were assayed in $\alpha 7$-expressing neurons in rat brain slices. Whole-cell recordings were performed in either hippocampal interneurons located in the CA1 stratum radiatum or magnocellular neurons located in the hypothalamic supraoptic nucleus. Both classes of neurons express functional $\alpha 7$-containing nAChRs (Alkondon et al., 1997; Jones and Yakel, 1997; Frazier et al., 1998a; Zaninetti et al., 2000, 2002). In hippocampal slices, ACh (0.2 $\mathrm{mM}$ ) evoked a rapidly activating inward current in all nine interneurons tested. Genistein potentiated the ACh-evoked current by a fac-
C

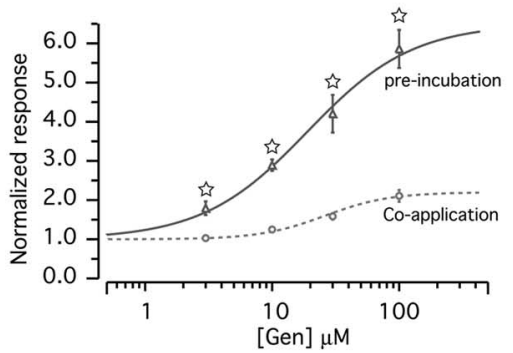

e

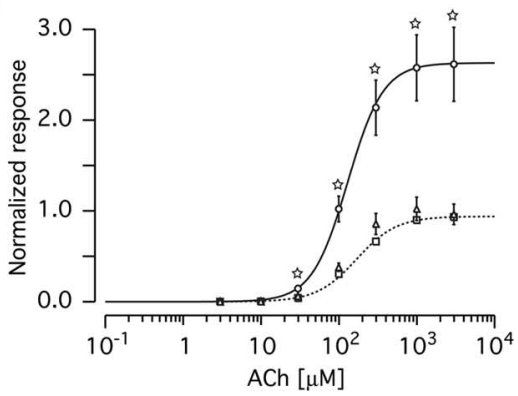

Figure 2. Genistein potentiates $\alpha 7 \mathrm{nAChRs}$ in Xenopus 0ocytes. 0ocytes expressing human $\alpha 7 \mathrm{nAChRs} \mathrm{were} \mathrm{challenged} \mathrm{under}$ two-electrode voltage clamp. $\boldsymbol{a}$, Recorded current during coapplication of ACh (200 $\mu \mathrm{m}, 2 \mathrm{~s}$; filled bars) with increasing concentrations of genistein (open bars). $\boldsymbol{b}$, ACh-evoked (200 $\mu \mathrm{M}, 2 \mathrm{~s})$ current before (gray traces) or after (1-2 h) incubation with (black traces). $\boldsymbol{c}$, Genistein (Gen) dose-response curves obtained from coapplication ( $\boldsymbol{a}$, cocorded in absence of genistein ( $n=8$, for all data points). The $\mathrm{EC}_{50}$ for genistein coapplication is $26 \mu \mathrm{m}$ and for . (supplemental Table 1, available at www.jneurosci.org as supplemental material). For all dose-response curves, data points are mean \pm SEM. Lines correspond to the best fit obtained with a Hill equation. Significant differences were calculated by unpaired, two-tailed Student's $t$ tests ( $s p<0.001)$.

tor of $2.1 \pm 0.4(n=4)$ (Fig. $4 a, c)$. This genistein-enhanced ACh current was sensitive to metyllycaconitine (MLA) $(10 \mathrm{nM} ; n=3)$, a competitive antagonist specific for $\alpha 7$ nAChRs (Fig. 4a). Genistein also caused a significant increase of the current evoked by ACh (1 $\mathrm{mM}$ ) in supraoptic magnocellular neurons (three neurons in three different slices) (Fig. $4 d, e$ ). Such currents are known to reflect $\alpha 7$ receptor activity and are blocked by $\alpha$-BT (Zaninetti et al., $2000)$. The genistein-induced potentiation was rapidly reversible after removal of the drug (Fig. $4 d, e$ ).

Together, these data show that genistein treatment potentiates $\alpha 7$ ACh-evoked currents. The potentiation is similar (2.1-fold to $\sim 3$ fold), in oocytes, SH-SY5Y cells, and hippocampal interneurons and occurs progressively during a $15 \mathrm{~min}$ incubation in supraoptic nucleus slices. Potentiation does not stem from direct genistein action on the $\alpha 7$ receptor channel but most likely occurs from indirect effects, i.e., inhibition of tyrosine kinases. The potentiation is rapidly reversible after drug wash-off in brain, $\mathrm{SH}-\alpha 7$ cells, and oocytes, implying that the critical phosphorylation/dephosphorylation steps occur with a rapid turnover shorter than $20 \mathrm{~min}$.

\section{Inhibition of tyrosine phosphatases decreases $\alpha 7$ ACh-evoked responses}

To assess the consequences of increased tyrosine phosphorylation for $\alpha 7$ function, we treated oocytes with pervanadate. Per- 
a

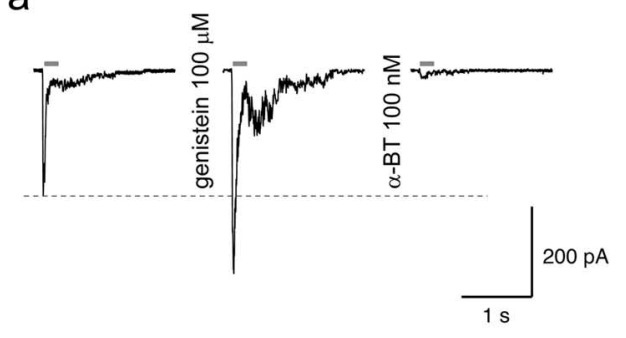

b

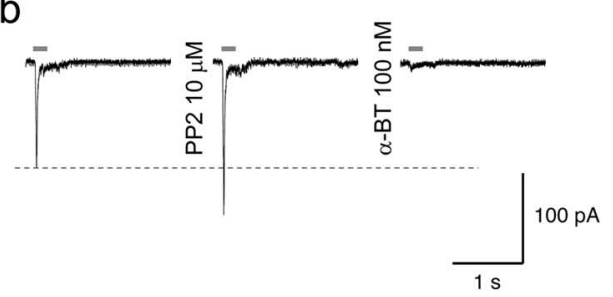

C

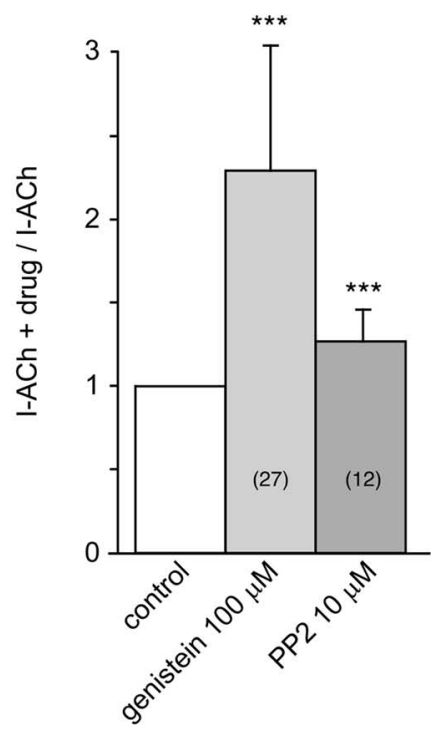

Figure 3. Genistein and PP2 potentiate ACh-evoked currents in SH- $\alpha 7$ cells. $\boldsymbol{a}$, Currents evoked by brief ACh test pulses ( $1 \mathrm{~mm}$, $200 \mathrm{~ms}$ ) were recorded in control conditions (left trace), after $1 \mathrm{~min}$ exposure to $100 \mu \mathrm{m}$ genistein (middle trace), and again after 1 min incubation with $100 \mathrm{~nm} \alpha$-BT (right trace). Bars above the traces indicate the duration of ACh application. Dashed line indicates the amplitude of the peak of the ACh-evoked current measured in control. $\boldsymbol{b}$, Recordings obtained in another cell using the same protocol but with exposure to PP2 (10 $\mu \mathrm{m})$. To avoid direct effects of genistein or PP2, cells were washed for $5 \mathrm{~s}$ before testing with ACh. All recordings were obtained in whole-cell patch-clamp configuration at a holding potential of $-100 \mathrm{mV}$. c, Ratios between ACh-evoked currents recorded after drug treatment and before drug treatment (control), measured for 27 genistein-treated and 12 PP2-treated cells, are represented. Paired Student's $t$ test computations of the current amplitude recorded after exposure to genistein or PP2 versus the value measured in the same cell in control (before drug treatment) indicate a highly significant increase attributable to both inhibitors $\left({ }^{* * *} p<0.001\right)$.

vanadate pretreatment decreased the peak amplitude of AChevoked currents (Fig. 5a,b), without substantially affecting current kinetics or the $\mathrm{EC}_{50}$ of ACh (supplemental Table 1, available at www.jneurosci.org as supplemental material). The pervanadate preincubation time could be as short as $30 \mathrm{~min}$ and still yielded decreased responses.

Reduction in current amplitude could, in principle, originate from a relocation of surface receptors to intracellular compartments or from a change in the responsiveness of the surface population of $\alpha 7 \mathrm{nAChRs}$ to ACh. To distinguish between these possibilities, we treated $\mathrm{SH}-\alpha 7$ cells with pervanadate and selectively precipitated surface or internal $\alpha 7$ receptors using biotin- $\alpha$-BT as described previously for muscle nAChRs in myotubes (Moransard et al., 2003) (for details, see Materials and Methods). $\alpha 7$ $\mathrm{nAChRs}$ were found to reside both at the surface and in intracellular compartments of SH- $\alpha 7$ cells (Fig. $5 c$ ). In untreated cells, $43 \pm 3 \%$ (mean \pm SEM; $n=4$ blots) of all $\alpha 7$ receptors were located at the surface. This value is similar to oocytes expressing $\alpha 7 \mathrm{nAChRs}$, in which $\sim 50 \%$ of all $\alpha 7$ receptors were recently found to reside at the surface (Cho et al., 2005). In SH- $\alpha 7$ cells, pervanadate caused phosphorylation only of the surface $\alpha 7$ nAChRs and did not reduce the number of surface receptors or alter the ratio between surface and intracellular receptors (Fig. $5 c, d)$. Thus, pervanadate leads to phosphorylation of $\alpha 7 \mathrm{nAChRs}$ selectively at the cell surface and inhibits $\alpha 7$ function, without detectable change in receptor distribution. The rapid timescale of the pervanadate effect on $\alpha 7$ activity (30 min preincubation) (Fig. $5 a, b)$ is consistent with the rapid turnover of $\alpha 7$ phosphorylation seen in Figure 1.

\section{Mutation of cytoplasmic tyrosine residues increases the $\alpha 7 \mathrm{nAChR}$ current amplitude}

The effects of genistein and pervanadate on $\alpha 7$ receptor function (Figs. 2-5) could be attributed to changes in levels of tyrosine phosphorylation of $\alpha 7 \mathrm{nAChRs}$ themselves or indirectly through (de)phosphorylation of other proteins. To distinguish between these possibilities, we first identified putative tyrosine phosphorylation sites in the $\alpha 7$ protein sequence. Most of the intracellular receptor portion is formed by the long cytoplasmic loop between transmembrane domains TM3 and TM4 (Chini et al., 1994). In human $\alpha 7$, this loop contains two tyrosine residues, Tyr-386 and Tyr-442. Computer algorithms predicted Tyr-442 as a consensus phosphorylation site, whereas Tyr-386 emerged as a phosphorylation site by sequence comparison with known phosphotyrosines in Torpedo nAChR subunits (Chini et al., 1994) (supplemental Fig. 1, available at www.jneurosci.org as supplemental material). The residues surrounding Tyr-386 and Tyr-442 showed a high degree of conservation across species (supplemental Fig. 1, available at www. jneurosci.org as supplemental material). Tyr-386 is part of a consensus motif, NXXY, for binding to phosphotyrosinebinding domains in signaling proteins such as the Shc family (Ware et al., 1996). Thus, Tyr-386 and Tyr-442 are strong candidates for phosphorylation.

We therefore substituted both Tyr-386 and Tyr- 442 by alanine using site-directed mutagenesis. Oocytes expressing the mutant $(\alpha 72 \mathrm{Y}-\mathrm{A})$ receptors displayed significantly larger $(\sim 2.5$ fold) ACh-evoked currents than those recorded in sibling oocytes expressing the wild-type receptors (Fig. 6a,b). No significant difference was, however, observed for either the current kinetics or the sensitivity to ACh (supplemental Table 1, available at www. jneurosci.org as supplemental material). Interestingly, the maximal evoked current $\left(I_{\max }\right)$ of $\alpha 72 \mathrm{Y}$-A receptors was comparable with the $I_{\max }$ in parallel genistein-treated cells expressing wildtype $\alpha 7$ nAChRs (Fig. $6 c$ ). Importantly, the $I_{\max }$ of $\alpha 72 \mathrm{Y}$-A receptors was insensitive to either genistein or pervanadate treatments (Fig. 6c). These data strongly suggest that the modulation of wild-type $\alpha 7 \mathrm{nAChRs}$ by these compounds originates mostly from changes in tyrosine phosphorylation of $\alpha 7$ receptors themselves. Dephosphorylation of $\alpha 7 \mathrm{nAChRs,} \mathrm{attributable} \mathrm{to}$ genistein or mutation of tyrosines, results in receptor potentiation, whereas phosphorylation, evoked by pervanadate, causes inhibition. Tyrosine phosphorylation of $\alpha 7$ thus negatively regulates $\alpha 7$ receptor activity.

\section{SFKs interact with the cytoplasmic loop of $\alpha 7 \mathrm{nAChRs}$}

To examine which tyrosine kinases phosphorylate and regulate $\alpha 7$ nAChRs, we focused on SFKs, because they, as well as $\alpha 7$ receptors, can modulate synaptic plasticity in the hippocampus (Lu et al., 1998; Ji et al., 2001). Because SFKs usually bind to their substrates, forming a complex (Thomas and Brugge, 1997), we first tested whether they interact with $\alpha 7$ receptors. We prepared 
lysates of SH- $\alpha 7$ cells and precipitated $\alpha 7$ nAChRs using biotin- $\alpha$-BT, followed by streptavidin-agarose. We identified $\alpha 7$ nAChR-associated SFKs by immunoblotting with Src-CT (Mittaud et al., 2001), a pan-Src antiserum reactive with several SFKs, including Src, Fyn, and Yes. This assay detected specific association of members of the Src family with $\alpha 7 \mathrm{nAChRs}$ (Fig. 7a). Using antibodies specific for single SFKs, we identified Src, Fyn, and Lyn as $\alpha 7$-associated kinases. These interactions were specific, because addition of free excess $\alpha$-BT to the lysates decreased the signal and because no specific association occurred between $\alpha 7$ nAChRs and $\mathrm{G} \beta$ subunits of trimeric G-proteins or Yes, despite the expression of these proteins in SH- $\alpha 7$ cells (Fig. $7 a$ and data not shown).

SH- $\alpha 7$ cells express functional $\alpha 7$ receptor channels at the surface (Fig. 3). To determine whether such receptors interact with SFKs, we selectively isolated surface $\alpha 7$ nAChRs from $\mathrm{SH}-\alpha 7$ cells by adding biotin- $\alpha$-BT to intact cells before lysis and indeed found associated SFKs (Fig. $7 b$ ). The amount of SFKs on surface $\alpha 7$ receptors was comparable with the amount of SFKs on total $\alpha 7 \mathrm{nAChRs,} \mathrm{suggesting} \mathrm{that}$ SFKs preferentially bind to $\alpha 7$ receptors at the cell surface (Fig. $7 b$ ).

To verify SFK interaction with functional $\alpha 7$ nAChRs in vivo, we used rat brain, in which $\alpha$-BT-binding receptors consist of $\alpha 7$ subunits in homomeric complexes (Drisdel and Green, 2000). We prepared brain extracts from P5 and P30 rats, precipitated $\alpha 7$ receptor with $\alpha$-BT coupled to Sepharose beads (Drisdel and Green, 2000), and detected specific association with SFKs (Fig. 7c). Thus, in both rat brain and human $\mathrm{SH}-\alpha 7$ cells, $\alpha$-BTbinding $\alpha 7 \mathrm{nAChRs}$ interact with members of the Src family.

Furthermore, we mapped the site on $\alpha 7$ for SFK interaction using bacterially expressed and purified GST fusion proteins (Fuhrer and Hall, 1996) containing portions of human $\alpha 7$ receptor. GST fusion proteins, attached to glutathione-Sepharose beads, were added to lysates of SH- $\alpha 7$ cells, and association of SFKs was analyzed by precipitation and Western blotting using pan-Src antibodies. In these pull-down assays, SFKs from SH- $\alpha 7$ cell extracts interacted with the $\alpha 7$ loop (GST- $\alpha$ 7loop protein) but not with an $\alpha 7$ portion comprising transmembrane domain TM4 and the C terminus (GST- $\alpha$ 7TM4CT protein) (Fig. $7 d$ ). As an additional control, SFKs did not interact with parental GST protein (Fig. 7d). In demonstrating interaction between SFKs and the $\alpha 7$ receptor loop, these experiments confirm the specific $\alpha 7$-SFK association shown by coprecipitation using $\alpha$-BT (Fig. $7 a-c$ ).

Collectively, these data demonstrate that functional, $\alpha$-BTbinding surface $\alpha 7 \mathrm{nAChRs}$ interact with SFKs. Most likely, these kinases bind by a direct protein-protein interaction to the intracellular loop between TM3 and TM4. b

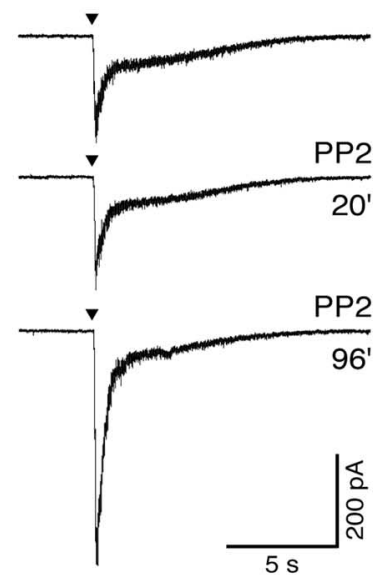

C
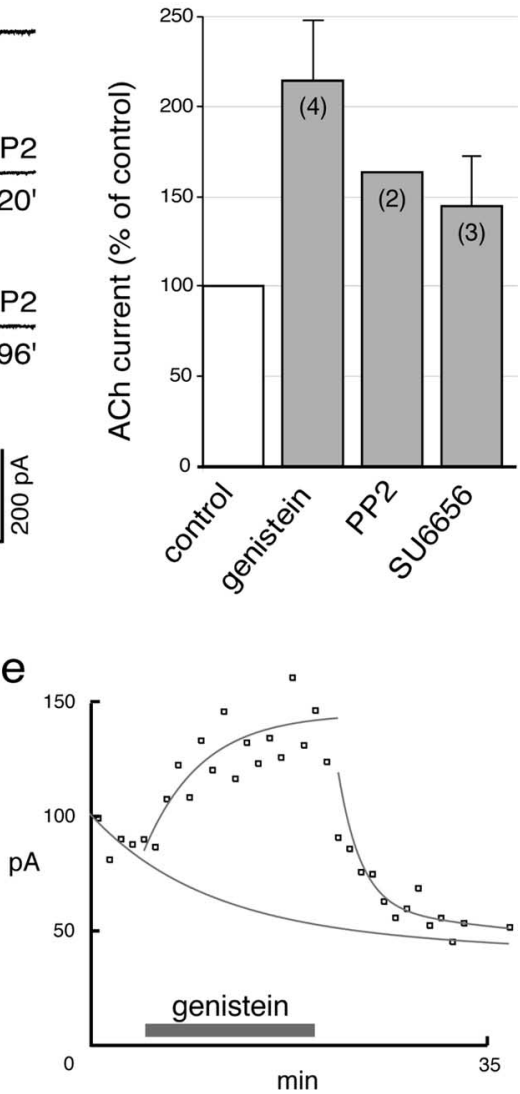

e

$\min$
15

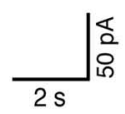

Figure 4. Genistein and specific SFK inhibitors potentiate native $\alpha 7$ nAChRs. $\boldsymbol{a}-\boldsymbol{c}$, Effect of genistein and of specific SFK initors on hippocampal CA1 interneurons. $\boldsymbol{a}$ represents current traces evoked by brief ACh pulses $(0.2 \mathrm{~mm}$; see Materials and (top trace), after genistein application (100 $\mu \mathrm{m}, 20 \mathrm{~min}$; middle trace), and in the presence of MLA genistein before observing a significant potentiation. $c$, Histogram showing the mean effects of genistein (100 $\mu \mathrm{M}), \mathrm{PP} 2(10 \mu \mathrm{M})$, and SU6656 (0.5 $\mu \mathrm{M})$ on the ACh-evoked current in hippocampal interneurons. Numbers indicate the number of neurons analyzed. $\boldsymbol{d}, \boldsymbol{e}$, Effect of genistein on the ACh-evoked current in magnocellular supraoptic neurons. $\boldsymbol{d}$ represents the mean current traces $(n=3)$ evoked by ACh pulses ( $1 \mathrm{~mm}$ ) in control conditions (left trace), after genistein application (100 $\mu \mathrm{m}, 15 \mathrm{~min}$; middle function of the recording time. Genistein was added to the perfusion solution for the $15 \mathrm{~min}$ period represented by the horizontal es through the data points are exponential best fits. Note that, despite a progressive decrease in the ACh peak current, probably attributable to receptor desensitization and run down, genistein markedly and reversibly increased the ACh response.

SFKs phosphorylate $\alpha 7$ nAChRs at the plasma membrane

To determine whether SFKs not only bind to but phosphorylate $\alpha 7$ receptors, we used the Src-family-specific inhibitors PP2 (Smith et al., 2001) and CGP77675 (Missbach et al., 1999; Mittaud et al., 2004). In SH- $\alpha 7$ cells treated with these compounds, pervanadate did not cause efficient phosphorylation of $\alpha 7$ nAChRs, as shown by biotin- $\alpha$-BT and streptavidin-agarose precipitation, followed by phosphotyrosine immunoblotting (Fig. $8 a, b$ ). In SH- $\alpha 7$ cell lysates analyzed without precipitation, phosphorylation of other cellular proteins still occurred in the presence of CGP77675 and pervanadate, showing specificity of the SFK-mediated $\alpha 7$ receptor phosphorylation process (Fig. $8 a, b)$. Use of another SFK-specific inhibitor, SU6656 (Blake et al., 2000), yielded the same result (data not shown). Thus, SFKs can specifically phosphorylate functional, $\alpha$-BT-binding $\alpha 7$ receptors in SH- $\alpha 7$ cells. It appears that SFK-mediated phosphoryla- 
a
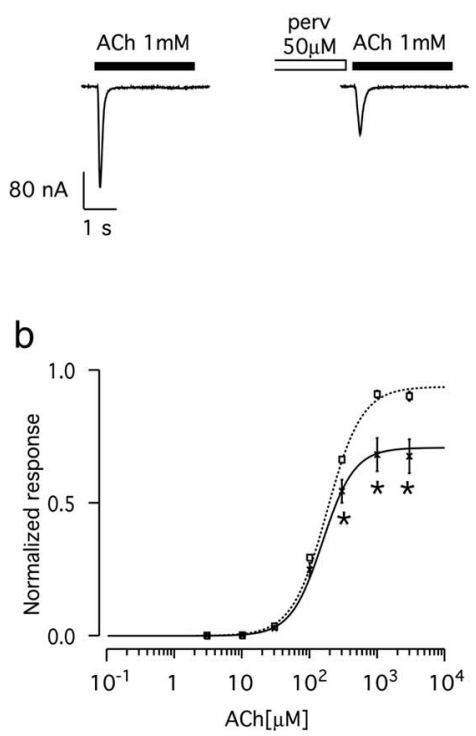

C
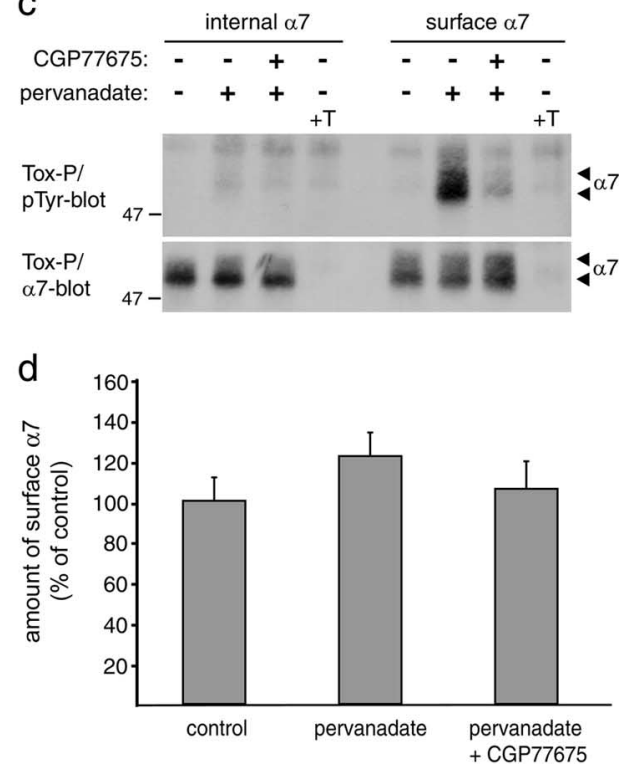

Figure 5. Pervanadate inhibits human $\alpha 7 \mathrm{nAChRs}$ in Xenopus 0ocytes. $\boldsymbol{a}$, ACh-evoked ( $1 \mathrm{~mm}, 3 \mathrm{~s}$ ) current without (left) or after $0.5-1$ h incubation with $50 \mu$ m pervanadate (perv, right). $\boldsymbol{b}$, ACh dose-response curve without (squares, dashed line; $n=28$ ) and after pervanadate treatment (crosses, solid line; $n=22$ ). Currents were evoked by successive test pulses ( $3 \mathrm{~s}$ ) with increasing ACh concentrations, applied every $90 \mathrm{~s}$. Currents were normalized to 1 at saturating ACh concentration (no perv). Data points are expressed as mean \pm SEM, and the lines correspond to the best fit with a Hill equation (supplemental Table 1, available at www.jneurosci.org as supplemental material). Significant differences between pervanadate and control treatments were calculated by unpaired, two-tailed Student's tests ( $\left.{ }^{*} p<0.01\right)$.c, SH- $\alpha 7$ cells were treated for 90 min with $10 \mu$ m CGP77675, followed by addition of $50 \mu \mathrm{m}$ pervanadate. In controls, these compounds were omitted or an excess of free $\alpha$-BT was added before precipitation $(+\mathrm{T})$. Intracellular or surface $\alpha 7$ receptors were precipitated using biotinylated $\alpha$-BT and analyzed by phosphotyrosine and $\alpha 7$ immunoblotting. Pervanadate causes phosphorylation of surface but not internal $\alpha 7$ receptors, and this phosphorylation originates from SFKs. Pervanadate, alone or with CGP77675, does not decrease the number of surface $\alpha 7$ receptors or affect internal $\alpha 7$. $\boldsymbol{d}, \alpha 7$ blots as shown in c were quantitated by densitometric scanning (mean $\pm \mathrm{SD} ; n=10$ ).

tion occurs rapidly, because a 20 min pervanadate treatment is sufficient to visualize it (Fig. $8 a, b$ ).

SFK-mediated $\alpha 7$ receptor phosphorylation occurred at the plasma membrane, because CGP77675 blocked pervanadateinduced phosphorylation of surface $\alpha 7$ receptors (Fig. 5c). Furthermore, CGP77675 treatment (when combined with pervanadate) did not affect the number of surface or internal $\alpha 7 \mathrm{nAChRs}$ (Fig. $5 c, d$ ), implying that SFK activity does not affect receptor distribution in SH- $\alpha 7$ cells.

We also used GST- $\alpha$ 7loop protein to assess phosphorylation of the two consensus tyrosine sites by SFKs. In the first approach, GST- $\alpha$ 7loop protein was added to lysates prepared from pervanadate- and PP2-treated SH- $\alpha 7$ cells. After pull-down, complexes were subjected to in vitro phosphorylation in the presence of ATP. Without PP2, GST- $\alpha$ 7loop protein was phosphorylated as shown by phosphotyrosine immunoblotting (Fig. $8 c$ ). PP2 reduced this signal, revealing that SFKs from $\mathrm{SH}-\alpha 7$ cells phosphorylated the $\alpha 7$ loop in the assay (Fig. $8 c$ ). This was observed for GST fusion proteins containing the human $\alpha 7$ loop (Fig. $8 c$ ) or the rat loop sequence (data not shown). In the second approach, wild-type and mutant forms of GST- $\alpha$ 7loop protein, lacking Tyr-386 and/or Tyr-442, were incubated with purified Src kinase. Wild-type and single mutants, but not the double mutant, were phosphorylated, illustrating that Src can phosphorylate both tyrosines within the $\alpha 7$ receptor loop (Fig. $8 d$ ). In both approaches, a 15 min incubation produced strong in vitro phosphorylation. This rapid phosphorylation suggests that the $\alpha 7$ $\mathrm{nAChR}$ is a direct substrate for SFKs.

\section{SFKs regulate $\alpha 7$ receptor function}

To determine the effect of SFKs on $\alpha 7$ receptor function, we used PP2 and SU6656 on oocytes expressing wild-type human $\alpha 7$ nAChRs. Oocytes were first challenged with brief ACh test pulses ( $1.25 \mathrm{~mm}, 1 \mathrm{~s})$ that evoked control currents of maximal amplitude and then incubated for $1 \mathrm{~h}$ or longer with either SU6656 or PP2. AChevoked currents were recorded again at the end of the incubation using the same pulse parameters. Plots of the ratio between the ACh-evoked currents after and before drug incubation are shown in Figure 9a. A significant increase in the ACh-evoked current was observed after incubation with SU6656 and PP2 but was absent for cells treated with control solution or with the inactive PP3 analog. In agreement with a dephosphorylation-dependent increase of the wild-type $\alpha 7$ receptor activity, none of the compounds tested significantly modified the amplitude of the AChevoked currents recorded in oocytes expressing the $\alpha 7-2 \mathrm{YA}$ mutant receptor (Fig. 9a). Thus, inhibiting SFKs increases the $\alpha 7 \mathrm{nAChR}$ activity, attributable to decreased phosphorylation of $\alpha 7$ receptors themselves.

We analyzed the effect of PP2 on AChevoked currents in SH- $\alpha 7$ cells. PP2 exposure caused a significant increase of the current in 12 of 15 cells tested (Fig. 3b,c) (determined by paired student's $t$ tests). When compared with parallel experiments using genistein, the PP2-induced increase was smaller (Fig. 3b,c), similar to the situation in oocytes.

We verified these findings for native $\alpha 7$ receptors by analyzing the effect of PP2 and SU6656 on ACh-evoked $\alpha 7$ nAChR responses in the hippocampus. Whole-cell recordings of CA1 stratum radiatum interneurons were performed in rat hippocampal slices, using $0.2 \mathrm{~mm}$ ACh test pulses. Incubation with PP2 ( $n=2$ interneurons) or SU6656 ( $n=3$ interneurons) for periods longer than $1 \mathrm{~h}$ caused a significant increase in ACh-evoked inward current, by factors of 1.6 (PP2) and $1.4 \pm 0.3$ (SU6656) (Fig. 4b,c).

Together, SFK inhibitors significantly potentiate $\alpha 7$ responses, most likely by receptor dephosphorylation. The effects are consistently smaller in the three preparations tested (oocytes, $\mathrm{SH}-\alpha 7$ cells, and hippocampal interneurons) when compared with genistein, suggesting that, besides the Src family, other kinases act on $\alpha 7$ nAChRs.

In a gain-of-function approach, we coexpressed human wildtype $\alpha 7 \mathrm{nAChRs}$ in oocytes together with $\mathrm{vSrc}$, a constitutively active form of Src. Functionally, vSrc corresponds to maximally activated Src kinase in which all inhibitory intramolecular interactions are displaced, leading to open kinase conformation and maximal kinase activity (Thomas and Brugge, 1997). vSrc has therefore been widely used to study regulation of ion channels by SFKs, often in the Xenopus oocyte expression system, and is a model molecule for the fully active cellular Src kinase (Holmes et al., 1996b; Nitabach et al., 2001, 2002).

We observed a significant reduction of the ACh-evoked cur- 
a

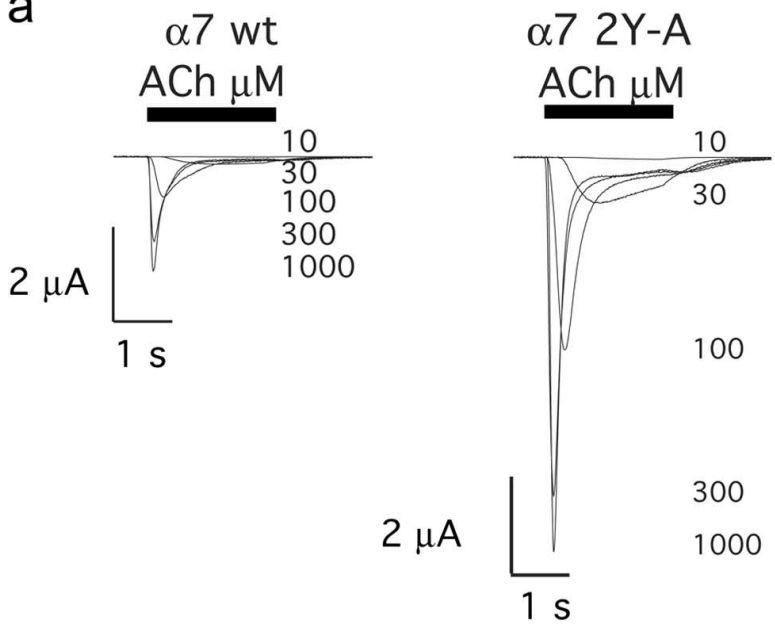

b

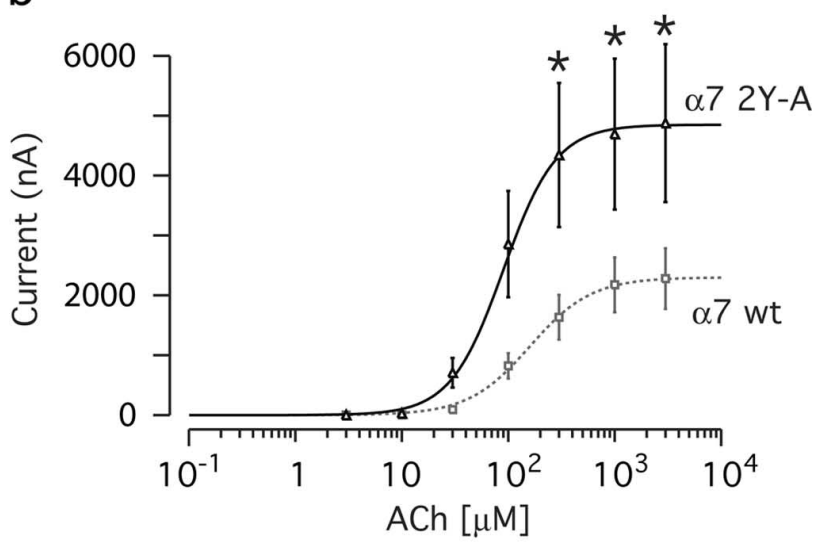

C

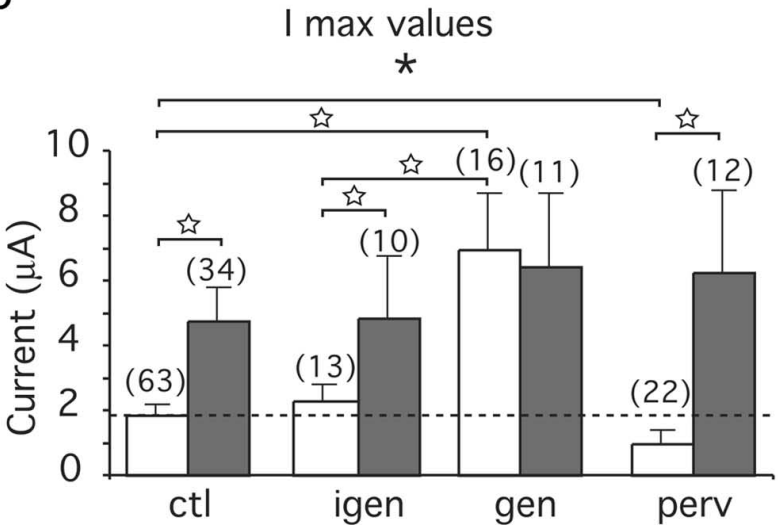

Figure 6. $\alpha 72 Y$-A mutant $n A C h R s$ exhibit larger ACh-evoked currents compared with wildtype $\alpha 7$. Xenopus 0ocytes expressing wild-type or $\alpha 72$ Y-A (Y386A, Y442A) receptor were recorded using two-electrode voltage clamp. $\boldsymbol{a}$, ACh-evoked currents for wild-type and mutant $\alpha 7$ nAChRs. Increasing ACh concentrations are indicated and expressed in micromolar. $\boldsymbol{b}, \mathrm{ACh}$ dose-response curves for wild-type $\alpha 7$ (squares, dashed line; $n=63$ ) and mutant $\alpha 72$ Y-A receptors (triangle, solid line; $n=34$ ). Currents were evoked by successive test pulses $(3 \mathrm{~s}$ ) with increasing ACh concentrations, applied every $90 \mathrm{~s}$. Lines through the data points correspond to the best fit with a Hill equation (supplemental Table 1, available at www.jneurosci.org as supplemental material). c, Maximal recorded currents $\left(I_{\max }\right)$ were plotted as a function of the drug applied at wild-type $\alpha 7$ (open bars) or $\alpha 72 Y$-A mutant receptor (gray bars). Genistein (gen) and genistin (igen) concentrations were $10 \mu \mathrm{M}$. The numbers in parentheses indicate the number of cells tested in each condition. Data are expressed as mean \pm SEM and show that ACh-evoked currents are higher for $\alpha 72$ Y-A nAChRs and that these receptors are insensitive to genistein and pervanadate (perv) treatment. Significant differences were calculated by unpaired, two-tailed Student's $t$ tests $\left({ }^{*} p<0.01 ; \star p<0.001\right)$. rent in oocytes coinjected with $\alpha 7$ receptor and the vSrc expression vector (Fig. 9b), without noticeable changes in the kinetics of the responses (data not shown). The reduction in $I_{\max }$ by vSrc was comparable with that caused by pervanadate treatment (Fig. $5 c$ ). As a control for nonspecific side effects of kinase expression, coinjection of a vSrc mutant (vSrc-KD), lacking kinase activity attributable to a point mutation in the ATP-binding site (Nitabach et al., 2001, 2002), produced no effect (Fig. 9b).

\section{SFKs are antagonized by phosphatases}

The pervanadate data show that $\alpha 7$ is a substrate for phosphatases and that $\alpha 7$ phosphorylation has a rapid turnover time $(<20$ min) revealing dynamic regulation by kinases and phosphatases (Fig. 1). The increased activity attributable to genistein, SU6656, or PP2 stems primarily from dephosphorylation of $\alpha 7$ receptors themselves, because $\alpha 72 \mathrm{Y}$-A receptors are not regulated by these compounds (Figs. 6, 9). Thus, in steady state, the balance between phosphatases and kinases, including SFKs, appears to produce a certain level of basal tyrosine phosphorylation of $\alpha 7 \mathrm{nAChRs}$. Our biochemical assays are, however, not sensitive enough to visualize basal $\alpha 7$ phosphorylation (Fig. 1). This most likely originates from persistent phosphatase activity that dephosphorylates $\alpha 7$ receptors during the precipitation with $\alpha$-BT. Several considerations support this hypothesis. First, in SH- $\alpha 7$ cells, $\alpha 7$ phosphorylation is unstable with rapid turnover. The overall phosphatase activity is pronounced as evidenced by the high level of dephosphorylation, because a 20 min pervanadate treatment produces strong $\alpha 7$ phosphorylation (Fig. 1). Second, although our lysis buffer contains an excess of phosphatase inhibitors (see Materials and Methods), phosphatase activity cannot be completely inactivated in the lysates and is present during the precipitation with $\alpha$-BT. Over the course of several trial experiments, we have observed that, in lysates made from pervanadate-treated SH- $\alpha 7$ cells, an extension of the biotin- $\alpha$-BT/streptavidin-agarose precipitation time (normal duration, $2 \mathrm{~h}$ ) significantly decreases the $\alpha 7$ phosphorylation signal without changing the amount of $\alpha 7$ protein (A. Wiesner and C. Fuhrer, unpublished observations). Third, some of the phosphatases acting on $\alpha 7$ may be associated with the receptor because, in adrenal medulla chromaffin cells, ganglionic-type nAChRs associate with phosphatases in a complex (van Hoek et al., 1997). Such association will increase the efficiency of receptor dephosphorylation and make it hard to block this process during $\alpha 7$ precipitation. Finally, shaker-type voltage-gated potassium channels are also associated and negatively regulated by Src through tyrosine phosphorylation (Holmes et al., 1996a; Nitabach et al., 2002). Tyrosine phosphatases act on these channels, such that their basal tyrosine phosphorylation level is low or undetectable in a Western blot, whereas pervanadate leads to strong channel phosphorylation (Holmes et al., 1996a; Nitabach et al., 2002). The similarity to $\alpha 7$ nAChRs suggests that phosphatase regulation of ion channels may be widespread, antagonize SFKs, and render detection of basal channel phosphorylation difficult.

Together, our data show that increasing $\alpha 7$ receptor phosphorylation by activation of Src or by inactivation of tyrosine phosphatases yields a comparable inhibitory effect on the AChevoked currents (Figs. 5, 9). Conversely, decreasing $\alpha 7 \mathrm{nAChR}$ phosphorylation through inhibition of SFKs causes potentiation of the ACh-triggered response (Figs. 3, 4, 9). Thus, SFKs are counteracted by phosphatases in phosphorylation of $\alpha 7$ receptors, and these kinases modulate the functional activity of $\alpha 7$ nAChRs. 
a

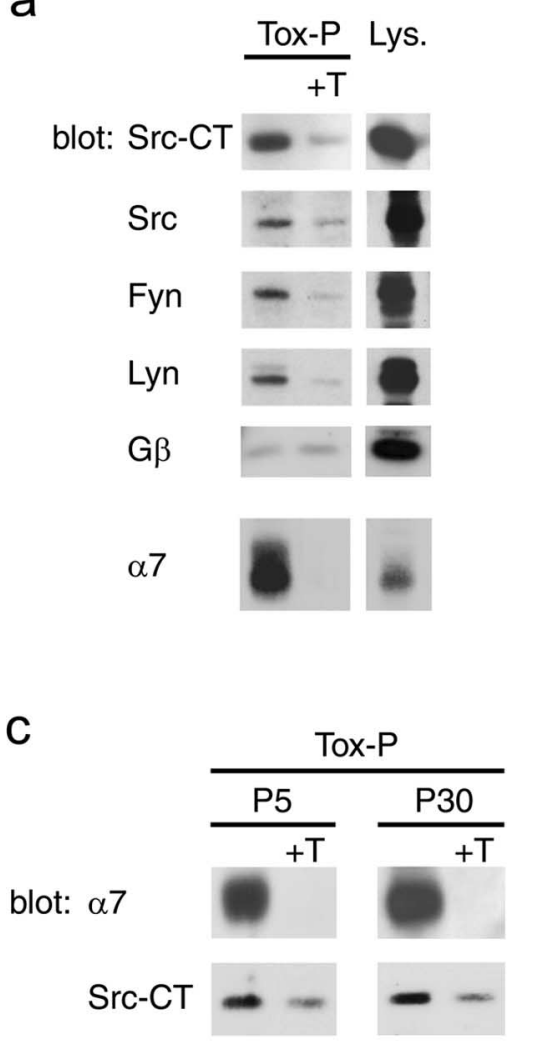

b

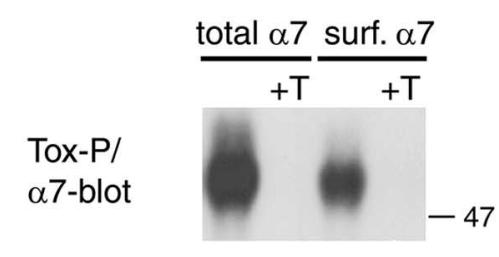

Tox-P/ Src-CT-blot

d

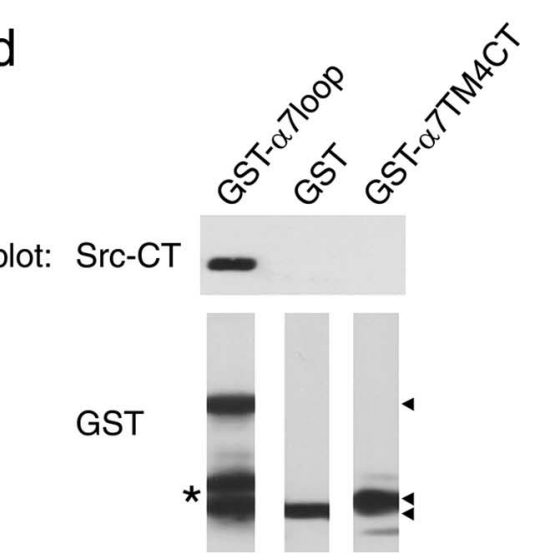

Figure 7. $\quad \alpha 7$ nAChRs interact with SFKs. $\boldsymbol{a}, \alpha 7$ receptors were precipitated from SH- $\alpha 7$ cells using biotinylated $\alpha$-BT followed by streptavidin-agarose (Tox-P), and associated proteins were identified by immunoblotting. As controls, excess free $\alpha$-BT was added before precipitation ( $+\mathrm{T})$, or a fraction of the lysate was analyzed without precipitation (Lys.). Pan-Src (Src-CT) and single kinase-specific antibodies show that $\alpha 7$ receptors associate with SFKs, including Src, Fyn, and Lyn, whereas no specific association occurs with the $\mathrm{G} \beta$ subunit of trimeric $\mathrm{G}$-proteins. $\boldsymbol{b}$, Surface or total $\alpha 7$ receptors were precipitated from SH- $\alpha 7$ cells and probed with Src-CT antibodies, showing that the association of $\alpha 7 \mathrm{nAChRs}$ with SFKs is prominent at the cell surface. $c$, Whole brains of P5 rats and forebrains of $\mathrm{P} 30$ rats were homogenized in NP-40-containing buffer, and $\alpha 7$ receptors were isolated using $\alpha$-BT coupled to Sepharose beads. Src-CT blotting reveals specific association of $\alpha 7 \mathrm{nAChRs}$ with SFKs in brain. $\boldsymbol{d}$, Lysates from SH- $\alpha 7$ cells were incubated with glutathione bead-bound GST-fusion proteins containing either the $\alpha 7$ loop (GST- $\alpha 7$ loop) or the fourth transmembrane domain and C-terminal rest (GST- $\alpha$ 7 TM4CT). Src-CT blotting of precipitated beads shows that SFKs bind specifically to the $\alpha 7$ loop. Arrowheads indicate the GST fusion proteins, and the asterisk denotes degradation products of GST- $\alpha 7$ loop.

\section{Kinase inhibition does not change amount and clustering of $\alpha 7$ receptors at the cell surface}

The increase in current amplitude observed after genistein or PP2 preincubation could be attributed either to an increase in the number of receptors present at the cell surface or to a modification of the receptor properties. Cho et al. (2005) have recently reported that, in Xenopus oocytes expressing rat $\alpha 7$ nAChRs, $\sim 50 \%$ of all receptors reside in intracellular compartments. Genistein caused SNARE (soluble N-ethylmaleimide-sensitive factor attachment protein receptor)-dependent insertion of some of these receptors into the plasma membrane, leading to a twofold increase in the amplitude of ACh-evoked currents, and this also occurred for mutant receptors lacking cytoplasmic tyrosines (Cho et al., 2005). We therefore determined, after genistein treatment, the level of surface receptors in oocytes by labeling with a saturating dose $(10 \mathrm{nM})$ of ${ }^{125} \mathrm{I}-\alpha$-BT. Data presented in Figure $10 a$ illustrate that genistein incubation does not cause a significant increase in the amount of radioactive labeling for wild-type $\alpha 7$ receptors. In oocytes expressing $\alpha 72$ Y-A receptors, more labeling was observed for both untreated and genistein-treated oocytes (Fig. 10a). However, given the broad range of expression levels between oocytes, well known from other studies (Yoshii et al., 1987; Corringer et al., 1999; Cruz-Martin et al., 2001), differences between wild-type and mutant receptors and genistein-treated and untreated cells remained nonsignificant.

We obtained very similar results in SH- $\alpha 7$ cells, because treatment with genistein, PP2, or pervanadate did not change the amount of surface $\alpha 7$ receptors as determined by labeling with ${ }^{125} \mathrm{I}-\alpha$-BT (Fig. 10b). We also precipitated, using biotin- $\alpha$-BT, intracellular or surface $\alpha 7$ receptors from these cells (as described before for Fig. 5) and found no increase in the amount of surface receptors when cells were treated with genistein or PP2 (Fig. $10 c, d)$. Finally, intact $\mathrm{SH}-\alpha 7$ cells were labeled with Alexa $488-\alpha$-BT and examined by fluorescence microscopy to visualize surface $\alpha 7$ receptors. Receptors were visible as clusters on cellular processes and the soma. Some of these clusters appear to be on small filopodiae emanating from the processes (Fig. 10e). The distribution of $\alpha 7$ receptor clusters on soma, processes, and filopodiae is very similar to hippocampal GABAergic interneurons (Kawai et al., 2002). Importantly, genistein and PP2 treatment did not produce any obvious changes in the number, size, intensity, or distribution of $\alpha 7$ clusters (Fig. 10e).

Collectively, these data demonstrate that genistein and PP2 do not significantly affect the amount or distribution of $\alpha 7$ receptor at the surface of SH- $\alpha 7$ cells. However, the same genistein or PP2 treatments significantly increase ACh-evoked current of $\alpha 7$ receptors in oocytes, $\mathrm{SH}-\alpha 7$ cells, and hippocampal interneurons (Figs. 2-4, 9). This increase, thus, does not stem from increased numbers of receptors at the surface but from a modification of the properties of $\alpha 7 \mathrm{nAChRs}$ present in the plasma membrane.

\section{Discussion}

In this work, we have examined the effects of tyrosine phosphorylation on nicotinic receptors in the CNS, focusing on $\alpha 7 \mathrm{nAChRs}$. We found that $\alpha 7$ receptors are rapidly phosphorylated and dephosphorylated and that dephosphorylated receptors are more active. Part of the responsible kinases are SFKs, because they bind and phosphorylate $\alpha 7 \mathrm{nAChRs}$ at the cell surface and modulate their functional properties. The balance between SFKs and phosphatases determines the net phosphorylation of $\alpha 7 \mathrm{nAChRs,} \mathrm{constituting} \mathrm{an} \mathrm{important}$ regulatory mechanism for the activity of receptors at the plasma membrane and offering an additional capacity for modulation of neuronal network functions.

\section{Changes in $\alpha 7$ nAChR phosphorylation modulate receptor activity}

Dephosphorylation of $\alpha 7$ receptors was achieved by genistein treatment. Although we observed that genistein causes at least two effects on the $\alpha 7$ functional activity in oocytes, we found strong potentiation of ACh-evoked currents after prolonged 
genistein treatment followed by a brief wash. Because genistein was removed during the ACh test pulse, we conclude that potentiation is attributable to inhibition of intracellular phosphorylation rather than direct genistein action on the nAChRs. ACh dose-response curves confirmed $\alpha 7$ receptor potentiation at all ACh concentrations after genistein preapplication but revealed little if any change in receptor sensitivity to ACh. In addition, the increase in current amplitude was not modified by BAPTA treatment, a condition known to minimize the contamination by calcium-activated chloride channels (Devillers-Thiery et al., 1992), further implying that genistein modulates $\alpha 7 \mathrm{nAChR}$ activity through a more direct mechanism, most likely phosphorylation. Importantly, we found comparable genistein potentiation of $\alpha 7$ responses in neuroblastoma cells, hippocampal CA1 interneurons, and supraoptic magnocellular neurons.

Confirming the genistein effect, mutant $\alpha 72$ Y-A receptors displayed a potentiation comparable with that of wild-type receptors in genistein-treated cells, and the activity of $\alpha 72 \mathrm{Y}$-A receptors was not affected by genistein or pervanadate. Finally, the importance of phosphorylation for $\alpha 7$ $\mathrm{nAChR}$ activity was demonstrated with pervanadate treatment. This caused decreased receptor activity that we attributed to an increase in $\alpha 7$ phosphorylation. Collectively, the data suggest that tyrosine phosphorylation of $\alpha 7 \mathrm{nAChRs}$ negatively regulates receptor activity.

\section{SFKs phosphorylate and regulate the activity of $\alpha 7 \mathrm{nAChRs}$ and are} antagonized by tyrosine phosphatases

We identified SFKs as tyrosine kinases that interact with the $\alpha 7$ loop and phosphorylate the receptor at the cell surface. Thereby, SFKs are positioned to functionally modulate $\alpha 7 \mathrm{nAChRs,} \mathrm{and}$ we indeed found increased $\alpha 7$ activity during treatment with specific SFK inhibitors, PP2 and SU6656 (supplemental Fig. 2, available at www.jneurosci.org as supplemental material). Conversely, coexpression of $\alpha 7 \mathrm{nAChRs}$ with vSrc reduced amplitudes of AChevoked currents in a manner similar to pervanadate.

Although PP2 and SU6656 caused a significant increase of the $\alpha 7$ ACh-evoked currents, their effects were smaller than genistein. This was observed in oocytes, $\mathrm{SH}-\alpha 7$ cells, and hippocampal slices. Because genistein is a broad-spectrum tyrosine kinase inhibitor and interferes with additional kinases besides SFKs (Akiyama et al., 1987), these data suggest that $\alpha 7$ receptors are also substrates for other yet unknown tyrosine kinases.

The effects of pervanadate show that $\alpha 7$ nAChR phosphorylation has a rapid turnover time of $<20 \mathrm{~min}$, revealing dynamic regulation by kinases and phosphatases. In such a manner, phosphatases could antagonize SFKs and be important control players to determine overall $\alpha 7$ receptor activity. Differences in SFK and/or phosphatase activities between tissue types could lead to tyrosines in the $\alpha 7$ loop. b

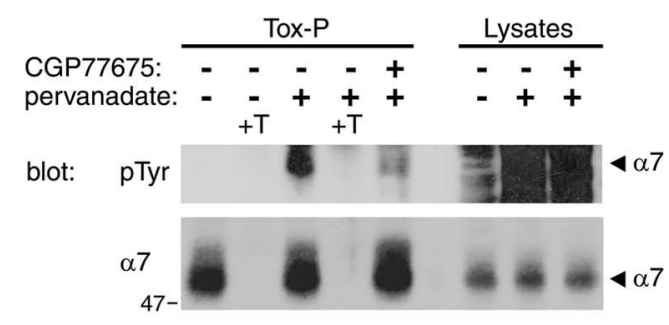

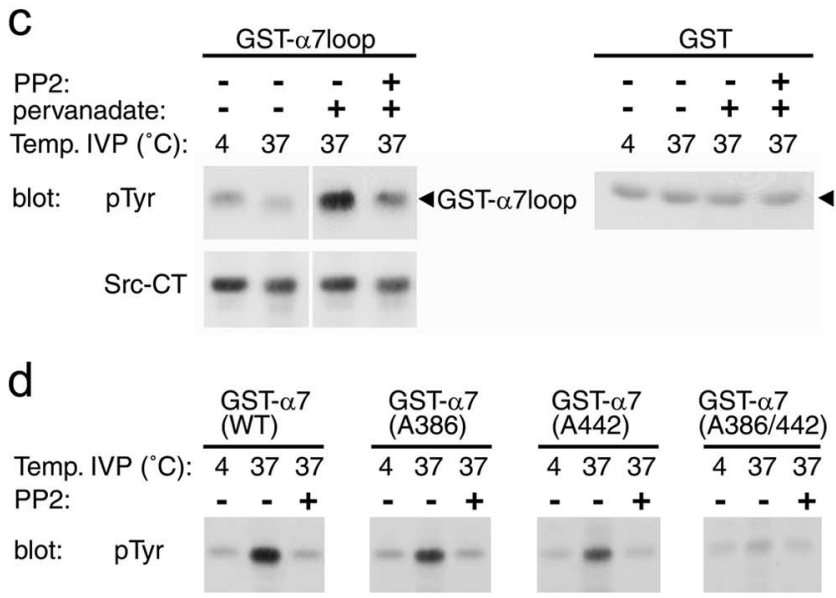

Figure 8. SFKs phosphorylate tyrosine residues in the $\alpha 7$ loop. $\boldsymbol{a}, \boldsymbol{b}, \mathrm{SH}-\alpha 7$ cells were treated for 10 min with PP 2 or for $45 \mathrm{~min}$ with CGP77675, followed by addition of $50 \mu \mathrm{m}$ pervanadate for $20 \mathrm{~min}$ in the presence of the SFK inhibitors. $\alpha$-BT-precipitated $\alpha 7$

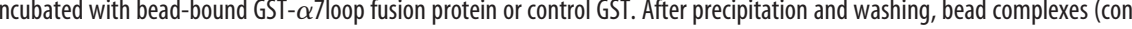
列 Purified GST-fusion proteins containing the $\alpha 7$ wild-type loop or mutants in which Tyr-386 and/or Tyr-442 are replaced 列 $4^{\circ} \mathrm{C}$ or $37^{\circ} \mathrm{C}$, with or without PP2. Phosphotyrosine blotting of reaction products shows that Src phosphorylates both

greatly different $\alpha 7$ responses and differences in their regulation in various cell types.

\section{Mechanism of $\alpha 7$ modulation by phosphorylation: an effect on receptor function but not number}

To interpret how phosphorylation may modulate $\alpha 7$ receptor activity, it is helpful to recall the principle of allosteric modulation. As shown previously for calcium, ivermectin, or 5-hydroxyindole, increase of the ACh-evoked current is accompanied by an increase in receptor sensitivity and apparent cooperativity that are the signatures of positive allosteric effectors (Galzi et al., 1996; Krause et al., 1998). Our observed lack of modification of $\alpha 7$ receptor sensitivity and cooperativity therefore suggests that reduced $\alpha 7 \mathrm{nAChR}$ phosphorylation by genistein does not act as a classical positive allosteric modulator. Alternative hypotheses include modulation of single-channel properties or increase in the number of responsive (activatable) receptors. Although our data do not reveal obvious changes in response time course, a way to discriminate between these two hypotheses would be to record single-channel activity in different phosphorylation conditions. Technical difficulties and singlechannel rundown prevents, however, reliable single $\alpha 7$ channel 

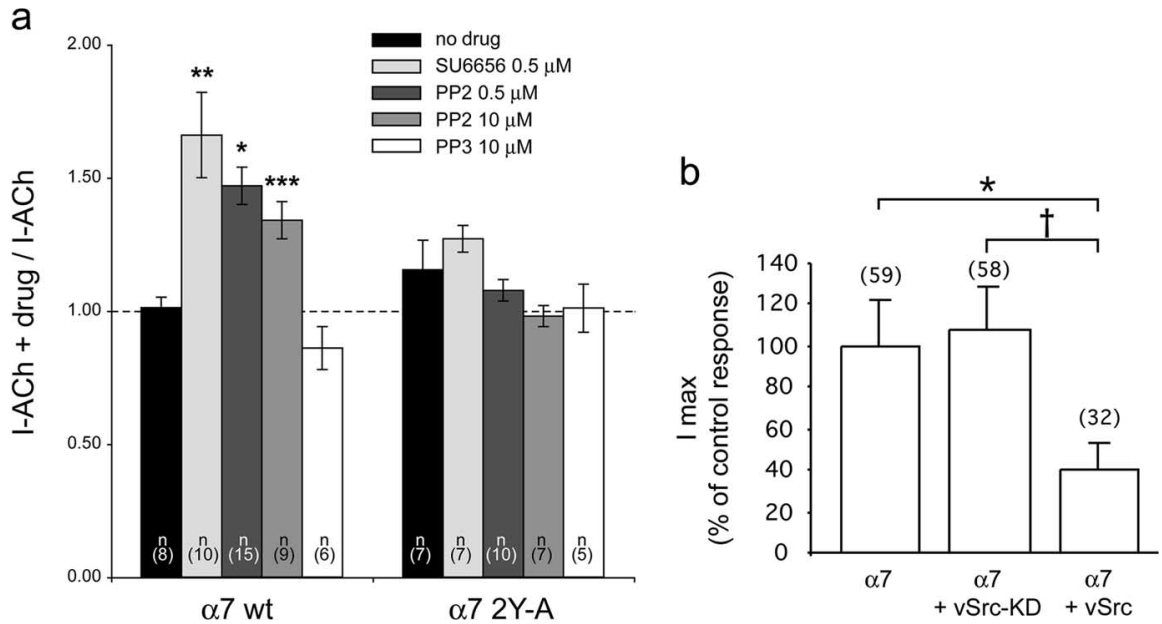

Figure 9. SFKs regulate $\alpha 7 \mathrm{nAChR}$ responses. $\boldsymbol{a}$, SFK-inhibitors SU6656 and PP2 increase the ACh-evoked currents in wild-type but not mutant $\alpha 7$ nAChRs. ACh-evoked currents were recorded in Xenopus 0ocytes expressing either wild-type human $\alpha 7$ ( $\alpha 7$ wt) or the human $\alpha 7-2 Y$ A mutant receptor before and after $1 \mathrm{~h}$ incubation with the indicated kinase inhibitor. Ratios between currents recorded after drug treatment and before treatment, measured in a series of cells from two 00cyte batches, are represented. $n$ represents the number of cells tested in each condition. Asterisks indicate statistically significant results (compared with no drug control), and error bars correspond to SEM ( ${ }^{*} p=0.007 ;{ }^{* *} p=0.002 ;{ }^{* *} p=0.001$, by Student's $t$ tests, using two samples with unequal variance and two-tail distribution). $\boldsymbol{b}$, DNA expression vectors encoding v $\mathrm{Src}$ or viral Src kinase without phosphorylation activity (vSrc-KD) were coinjected with human $\alpha 7 \mathrm{nAChR}$ vector in Xenopus oocytes. $I_{\text {max }}$ evoked by $1 \mathrm{~mm}$ ACh during $2 \mathrm{~s}$, is reduced by more than $50 \%$ when $v S r c$ is present compared with $I_{\max }$ in control, but no effect is observed when vSrc-KD is coexpressed. Data are expressed as mean \pm SEM. The number of cells tested is indicated in parentheses. Significant differences were calculated by unpaired, two-tailed Student's $t$ tests $\left({ }^{*} p<0.01 ; \uparrow p<0.05\right.$ ).

measurements to be done over time (Alkondon et al., 1994; Buisson et al., 1996; Liu and Berg, 1999).

We find that the number and clustering of receptors at the surface of oocytes and $\mathrm{SH}-\alpha 7$ cells is not significantly modified by phosphorylation. Thus, genistein- and PP2-induced potentiation of $\alpha 7 \mathrm{nAChRs}$ responses must stem from mechanisms other than insertion of additional receptors into the cell membrane. Most likely, phosphorylation affects the number of activatable receptors within the plasma membrane such that dephosphorylated receptors are responsive, whereas phosphorylated receptors are probably nonresponsive (supplemental Fig. 2, available at www.jneurosci.org as supplemental material). In agreement with this hypothesis, mean current amplitudes observed for $\alpha 72$ Y-A receptors are significantly larger without changes in response time course.

Cho et al. (2005) have recently found a twofold genisteininduced receptor potentiation in oocytes that occurs also for tyrosine-mutated receptors and was attributed to new surface receptor insertion. Although the reasons for the differences between this and our study remain unclear, the following aspect deserves attention. Like in the Cho et al. study, higher genistein concentrations potentiate $\alpha 7$ responses in oocytes threefold up to fivefold. The magnitude of such potentiation is incompatible with the sole hypothesis of receptor insertion. Namely, because only $50 \%$ of all receptors are internal (Cho et al., 2005), this could account for at most a twofold potentiation. Therefore, additional mechanisms independent of receptor trafficking must exist, and our data provide first evidences for these mechanisms. This novel hypothesis is supported by various observations (Fig. 10), most importantly by the absence of significant increase in receptor number, detected using ${ }^{125} \mathrm{I}-\alpha$-BT, in both genistein-treated oocytes and SH- $\alpha 7$ cells.

Previously, phosphorylation was described for nAChRs in the periphery. Phosphorylation on tyrosine or serine/threonine of Torpedo electric organ receptors to a high stoichiometry in vitro causes subtle changes in desensitization kinetics but not in $I_{\max }$ (Huganir et al., 1986; Hopfield et al., 1988). In adrenal medulla chromaffin cells, Src potentiates ganglionic-type heteromeric nAChRs in the secretion of catecholamines (Wang et al., 2004). In mammalian muscle, SFKs interact with the nAChR (Fuhrer and Hall, 1996) and play a role in clustering of nAChRs at the endplate (Mittaud et al., 2001, 2004; Mohamed et al., 2001; Smith et al., 2001). Thus, phosphorylation and SFKs affect peripheral nAChRs in many different ways, depending on tissue, subunittype of nAChRs, and functional role of the receptors.

\section{Possible roles of SFKs and tyrosine phosphorylation of $\alpha 7$ receptors in CNS neural circuits}

Because SFK and phosphatase activities are highly regulated by different signals (Thomas and Brugge, 1997), the control of the end level of phosphorylation offers a possibility of fine-tuning $\alpha 7$ receptor activity. This could play a role in various $\alpha 7 \mathrm{nAChR}$ mediated processes. At the cellular and synaptic level, calcium influx through $\alpha 7$ receptors activates various downstream signaling pathways (Dajas-Bailador and Wonnacott, 2004). To control such activation and avoid calcium toxicity, the activity of $\alpha 7$ receptors must be precisely controlled and may involve (de)phosphorylation.

At the neuronal circuit level, it is interesting that phosphorylated $\alpha 7 \mathrm{nAChRs}$ are less active: this is in contrast to NMDA receptors, which are potentiated by Src and tyrosine phosphorylation (Yu et al., 1997), but similar to shaker-type voltage-gated potassium channels, which are inhibited by vSrc (Holmes et al., 1996b; Nitabach et al., 2002). $\alpha 7$ nAChRs and NMDA receptors have some overlapping functions, because both receptors are highly permeable for calcium and important in CA1 hippocampal LTP (Lu et al., 1998; Dani, 2001; Ji et al., 2001). SFK activation may thus act in LTP induction in several ways: by potentiating NMDA receptors in pyramidal cells (Lu et al., 1998) and by concomitantly inhibiting postsynaptic $\alpha 7 \mathrm{nAChRs}$ in GABAergic interneurons, thereby facilitating disinhibition of pyramidal cells. Such a model is supported by our finding that SFK inhibition in hippocampal slices increases the $\alpha 7$ receptor activity in CA1 interneurons. The activity of postsynaptic $\alpha 7$ receptors on hippocampal inhibitory interneurons is also linked to auditory gating (Jones et al., 1999; Martin et al., 2004). It would be interesting to determine whether $\alpha 7$ phosphorylation influences the gating process, changes of which are strongly associated with schizophrenia. Regulation by phosphorylation may also be important for presynaptic $\alpha 7 \mathrm{nAChRs}$ that control neurotransmitter release.

Such mechanisms, using presynaptic and/or postsynaptic $\alpha 7$ nAChRs, can allow neurons to regulate the weight of their synaptic transmission, allow neural circuits to undergo plasticity, and fine-tune neuronal survival. In this sense, $\alpha 7$ phosphorylation mechanisms could be seen as a higher hierarchical possibility to modulate activity and signaling in neural networks. Such modulation may form a basis for the various emerging roles of $\alpha 7$ $\mathrm{nAChRs}$ from synaptic to systems level, including addiction, memory, and neurological disease. 
a

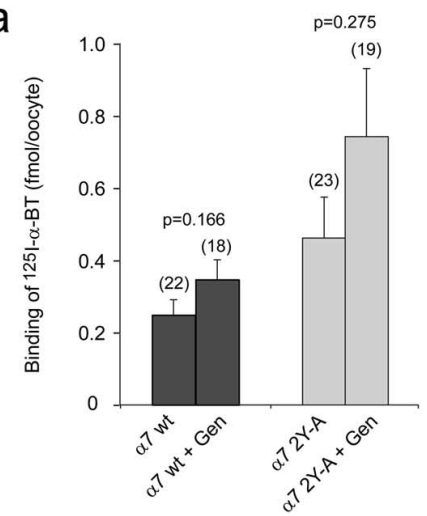

C

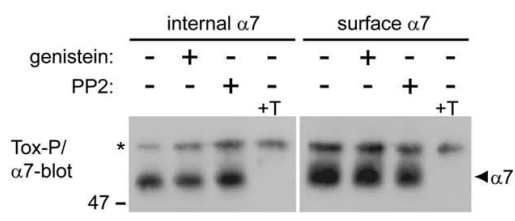

e

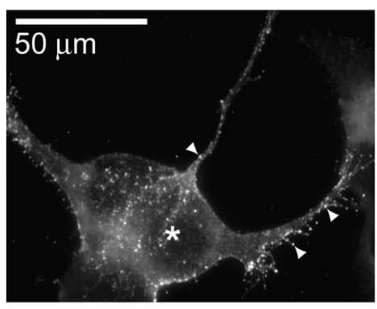

control

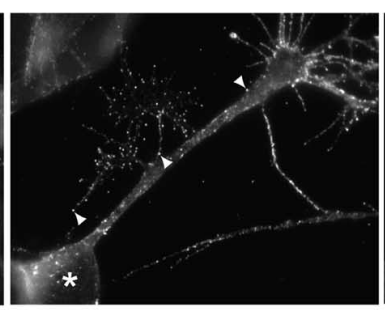

genistein

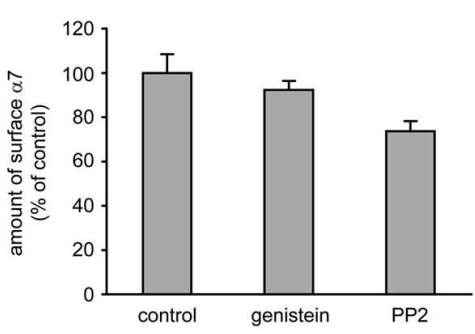

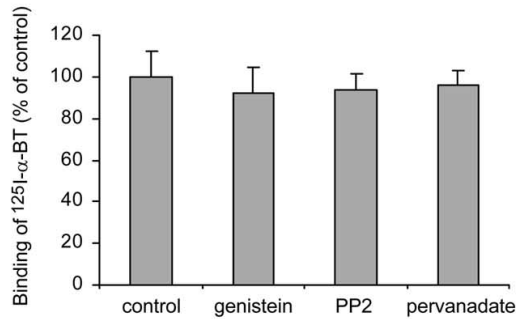

d and methyllycaconitine-sensitive nicotinic receptors mediate fast synaptic transmission in interneurons of rat hippocampal slices. Brain Res 810:257-263.

Balduzzi R, Cupello A, Robello M (2002) Modulation of the expression of $\mathrm{GABA}(\mathrm{A})$ receptors in rat cerebellar granule cells by protein tyrosine kinases and protein kinase C. Biochim Biophys Acta 1564:263-270.

Berg DK, Conroy WG (2002) Nicotinic alpha 7 receptors: synaptic options and downstream signaling in neurons. J Neurobiol 53:512-523.

Blake RA, Broome MA, Liu X, Wu J, Gishizky M, Sun L, Courtneidge SA (2000) SU6656, a selective src family kinase inhibitor, used to probe growth factor signaling. Mol Cell Biol 20:9018-9027.

Blom N, Gammeltoft S, Brunak S (1999) Sequence and structure-based prediction of eukaryotic protein phosphorylation sites. J Mol Biol 294:1351-1362.

Buisson B, Bertrand D (2001) Chronic exposure to nicotine upregulates the human $\alpha 4 \beta 2$ nicotinic acetylcholine receptor function. J Neurosci 21:1819-1829.

Buisson B, Gopalakrishnan M, Arneric SP, Sullivan JP, Bertrand D (1996) Human $\alpha 4 \beta 2$ neuronal nicotinic acetylcholine receptor in HEK 293 cells: a patch-clamp study. J Neurosci 16:7880-7891.

Chini B, Raimond E, Elgoyhen AB, Moralli D, Balzaretti M, Heinemann S (1994) Molecular cloning and chromosomal localization of the human alpha 7-nicotinic receptor subunit gene (CHRNA7). Genomics 19:379-381.

Cho CH, Song W, Leitzell K, Teo E, Meleth AD, Quick MW, Lester RA (2005) Rapid upregulation of $\alpha 7$ nicotinic acetylcholine receptors by tyrosine dephosphorylation. J Neurosci 25:3712-3723.

Corringer PJ, Bertrand S, Galzi JL, DevillersThiery A, Changeux JP, Bertrand D (1999) Mutational analysis of the charge selectivity filter of the alpha7 nicotinic acetylcholine receptor. Neuron 22:831-843.

Cruz-Martin A, Mercado JL, Rojas LV, McNamee MG, Lasalde-Dominicci JA (2001) Tryptophan substitutions at lipid-exposed positions of the gamma M3 transmembrane domain increase the macroscopic ionic current response of the Torpedo californica nicotinic acetylcholine receptor. J Membr Biol 183:61-70.

Dajas-Bailador F, Wonnacott S (2004) Nicotinic acetylcholine receptors and the regulation of neuronal signalling. Trends Pharmacol Sci 25:317-324.

Dajas-Bailador FA, Soliakov L, Wonnacott S (2002) Nicotine activates the extracellular signalregulated kinase $1 / 2$ via the alpha7 nicotinic acetylcholine receptor and protein kinase $\mathrm{A}$, in $\mathrm{SH}$ SY5Y cells and hippocampal neurones. J Neurochem 80:520-530.

Dani JA (2001) Overview of nicotinic receptors

\section{References}

Akiyama T, Ishida J, Nakagawa S, Ogawara H, Watanabe S, Itoh N, Shibuya M, Fukami Y (1987) Genistein, a specific inhibitor of tyrosine-specific protein kinases. J Biol Chem 262:5592-5595.

Alkondon M, Reinhardt S, Lobron C, Hermsen B, Maelicke A, Albuquerque EX (1994) Diversity of nicotinic acetylcholine receptors in rat hippocampal neurons. II. The rundown and inward rectification of agonistelicited whole-cell currents and identification of receptor subunits by in situ hybridization. J Pharmacol Exp Ther 271:494-506.

Alkondon M, Pereira EF, Barbosa CT, Albuquerque EX (1997) Neuronal nicotinic acetylcholine receptor activation modulates gammaaminobutyric acid release from CA1 neurons of rat hippocampal slices. J Pharmacol Exp Ther 283:1396-1411.

Alkondon M, Pereira EF, Albuquerque EX (1998) Alpha-bungarotoxinand their roles in the central nervous system. Biol Psychiatry 49:166-174.

Devillers-Thiery A, Galzi JL, Bertrand S, Changeux JP, Bertrand D (1992) Stratified organization of the nicotinic acetylcholine receptor channel. NeuroReport 3:1001-1004.

Drisdel RC, Green WN (2000) Neuronal $\alpha$-bungarotoxin receptors are $\alpha 7$ subunit homomers. J Neurosci 20:133-139.

Eisele JL, Bertrand S, Galzi JL, Devillers-Thiery A, Changeux JP, Bertrand D (1993) Chimaeric nicotinic-serotonergic receptor combines distinct ligand binding and channel specificities. Nature 366:479-483.

Frazier CJ, Rollins YD, Breese CR, Leonard S, Freedman R, Dunwiddie TV (1998a) Acetylcholine activates an $\alpha$-bungarotoxin-sensitive nicotinic current in rat hippocampal interneurons, but not pyramidal cells. J Neurosci 18:1187-1195.

Frazier CJ, Buhler AV, Weiner JL, Dunwiddie TV (1998b) Synaptic poten- 
tials mediated via $\alpha$-bungarotoxin-sensitive nicotinic acetylcholine receptors in rat hippocampal interneurons. J Neurosci 18:8228-8235.

Fuhrer C, Hall ZW (1996) Functional interaction of Src family kinases with the acetylcholine receptor in C2 myotubes. J Biol Chem 271:32474-32481.

Galzi JL, Edelstein SJ, Changeux J (1996) The multiple phenotypes of allosteric receptor mutants. Proc Natl Acad Sci USA 93:1853-1858.

Grant SG, O'Dell TJ, Karl KA, Stein PL, Soriano P, Kandel ER (1992) Impaired long-term potentiation, spatial learning, and hippocampal development in fyn mutant mice. Science 258:1903-1910.

Groot Kormelink PJ, Luyten WH (1997) Cloning and sequence of fulllength cDNAs encoding the human neuronal nicotinic acetylcholine receptor (nAChR) subunits beta 3 and beta 4 and expression of seven $n A C h R$ subunits in the human neuroblastoma cell line SH-SY5Y and/or IMR-32. FEBS Lett 400:309-314.

Holmes TC, Fadool DA, Levitan IB (1996a) Tyrosine phosphorylation of the Kv1.3 potassium channel. J Neurosci 16:1581-1590.

Holmes TC, Fadool DA, Ren R, Levitan IB (1996b) Association of Src tyrosine kinase with a human potassium channel mediated by $\mathrm{SH} 3$ domain. Science 274:2089-2091.

Hopfield JF, Tank DW, Greengard P, Huganir RL (1988) Functional modulation of the nicotinic acetylcholine receptor by tyrosine phosphorylation. Nature 336:677-680.

Hu M, Liu QS, Chang KT, Berg DK (2002) Nicotinic regulation of CREB activation in hippocampal neurons by glutamatergic and nonglutamatergic pathways. Mol Cell Neurosci 21:616-625.

Huang RQ, Fang MJ, Dillon GH (1999) The tyrosine kinase inhibitor genistein directly inhibits GABAA receptors. Brain Res Mol Brain Res 67:177-183.

Huganir RL, Delcour AH, Greengard P, Hess GP (1986) Phosphorylation of the nicotinic acetylcholine receptor regulates its rate of desensitization. Nature 321:774-776.

Huh KH, Fuhrer C (2002) Clustering of nicotinic acetylcholine receptors: from the neuromuscular junction to interneuronal synapses. Mol Neurobiol 25:79-112.

Jassar BS, Ostashewski PM, Jhamandas JH (1997) GABAA receptor modulation by protein tyrosine kinase in the rat diagonal band of Broca. Brain Res 775:127-133.

Ji D, Lape R, Dani JA (2001) Timing and location of nicotinic activity enhances or depresses hippocampal synaptic plasticity. Neuron 31:131-141.

Jones S, Yakel JL (1997) Functional nicotinic ACh receptors on interneurones in the rat hippocampus. J Physiol (Lond) 504:603-610.

Jones S, Sudweeks S, Yakel JL (1999) Nicotinic receptors in the brain: correlating physiology with function. Trends Neurosci 22:555-561.

Kawai H, Zago W, Berg DK (2002) Nicotinic $\alpha 7$ receptor clusters on hippocampal GABAergic neurons: regulation by synaptic activity and neurotrophins. J Neurosci 22:7903-7912.

Kihara T, Shimohama S, Sawada H, Honda K, Nakamizo T, Shibasaki H, Kume T, Akaike A (2001) alpha 7 nicotinic receptor transduces signals to phosphatidylinositol 3-kinase to block A beta-amyloid-induced neurotoxicity. J Biol Chem 276:13541-13546.

Krause RM, Buisson B, Bertrand S, Corringer PJ, Galzi JL, Changeux JP, Bertrand D (1998) Ivermectin: a positive allosteric effector of the alpha7 neuronal nicotinic acetylcholine receptor. Mol Pharmacol 53:283-294.

Levin ED (2002) Nicotinic receptor subtypes and cognitive function. J Neurobiol 53:633-640.

Liu Q, Berg DK (1999) Actin filaments and the opposing actions of CaM kinase II and calcineurin in regulating $\alpha 7$-containing nicotinic receptors on chick ciliary ganglion neurons. J Neurosci 19:10280-10288.

Liu Q, Kawai H, Berg DK (2001) beta-Amyloid peptide blocks the response of alpha 7-containing nicotinic receptors on hippocampal neurons. Proc Natl Acad Sci USA 98:4734-4739.

Lu YM, Roder JC, Davidow J, Salter MW (1998) Src activation in the induction of long-term potentiation in CA1 hippocampal neurons. Science 279:1363-1367.

Mansvelder HD, McGehee DS (2000) Long-term potentiation of excitatory inputs to brain reward areas by nicotine. Neuron 27:349-357.

Martin LF, Kem WR, Freedman R (2004) Alpha-7 nicotinic receptor agonists: potential new candidates for the treatment of schizophrenia. Psychopharmacology (Berl) 174:54-64.

Meier T, Perez GM, Wallace BG (1995) Immobilization of nicotinic acetylcholine receptors in mouse $\mathrm{C} 2$ myotubes by agrin-induced protein tyrosine phosphorylation. J Cell Biol 131:441-451.

Missbach M, Jeschke M, Feyen J, Muller K, Glatt M, Green J, Susa M (1999) A novel inhibitor of the tyrosine kinase Src suppresses phosphorylation of its major cellular substrates and reduces bone resorption in vitro and in rodent models in vivo. Bone 24:437-449.

Mittaud P, Marangi PA, Erb-Vogtli S, Fuhrer C (2001) Agrin-induced activation of acetylcholine receptor-bound Src family kinases requires Rapsyn and correlates with acetylcholine receptor clustering. J Biol Chem 276:14505-14513.

Mittaud P, Camilleri AA, Willmann R, Erb-Vogtli S, Burden SJ, Fuhrer C (2004) A single pulse of agrin triggers a pathway that acts to cluster acetylcholine receptors. Mol Cell Biol 24:7841-7854.

Mohamed AS, Rivas-Plata KA, Kraas JR, Saleh SM, Swope SL (2001) Srcclass kinases act within the agrin/MuSK pathway to regulate acetylcholine receptor phosphorylation, cytoskeletal anchoring, and clustering. J Neurosci 21:3806-3818.

Moransard M, Borges LS, Willmann R, Marangi PA, Brenner HR, Ferns MJ, Fuhrer C (2003) Agrin regulates rapsyn interaction with surface acetylcholine receptors, and this underlies cytoskeletal anchoring and clustering. J Biol Chem 278:7350-7359.

Nitabach MN, Llamas DA, Araneda RC, Intile JL, Thompson IJ, Zhou YI, Holmes TC (2001) A mechanism for combinatorial regulation of electrical activity: potassium channel subunits capable of functioning as Src homology 3-dependent adaptors. Proc Natl Acad Sci USA 98:705-710.

Nitabach MN, Llamas DA, Thompson IJ, Collins KA, Holmes TC (2002) Phosphorylation-dependent and phosphorylation-independent modes of modulation of shaker family voltage-gated potassium channels by SRC family protein tyrosine kinases. J Neurosci 22:7913-7922.

Ogier R, Raggenbass M (2003) Action of tachykinins in the rat hippocampus: modulation of inhibitory synaptic transmission. Eur J Neurosci 17:2639-2647.

Peng X, Katz M, Gerzanich V, Anand R, Lindstrom J (1994) Human alpha 7 acetylcholine receptor: cloning of the alpha 7 subunit from the SH-SY5Y cell line and determination of pharmacological properties of native receptors and functional alpha 7 homomers expressed in Xenopus oocytes. Mol Pharmacol 45:546-554.

Picciotto MR, Zoli M (2002) Nicotinic receptors in aging and dementia. J Neurobiol 53:641-655.

Puchacz E, Buisson B, Bertrand D, Lukas RJ (1994) Functional expression of nicotinic acetylcholine receptors containing rat alpha 7 subunits in human SH-SY5Y neuroblastoma cells. FEBS Lett 354:155-159.

Shaw S, Bencherif M, Marrero MB (2002) Janus kinase 2, an early target of alpha 7 nicotinic acetylcholine receptor-mediated neuroprotection against Abeta-(1-42) amyloid. J Biol Chem 277:44920-44924.

Smith CL, Mittaud P, Prescott ED, Fuhrer C, Burden SJ (2001) Src, Fyn, and Yes are not required for neuromuscular synapse formation but are necessary for stabilization of agrin-induced clusters of acetylcholine receptors. J Neurosci 21:3151-3160.

Thomas SM, Brugge JS (1997) Cellular functions regulated by Src family kinases. Annu Rev Cell Dev Biol 13:513-609.

van Hoek ML, Allen CS, Parsons SJ (1997) Phosphotyrosine phosphatase activity associated with c-Src in large multimeric complexes isolated from adrenal medullary chromaffin cells. Biochem J 326:271-277.

Wagner K, Edson K, Heginbotham L, Post M, Huganir RL, Czernik AJ (1991) Determination of the tyrosine phosphorylation sites of the nicotinic acetylcholine receptor. J Biol Chem 266:23784-23789.

Wang K, Hackett JT, Cox ME, Van Hoek M, Lindstrom JM, Parsons SJ (2004) Regulation of the neuronal nicotinic acetylcholine receptor by SRC family tyrosine kinases. J Biol Chem 279:8779-8786.

Ware MD, Rosten P, Damen JE, Liu L, Humphries RK, Krystal G (1996) Cloning and characterization of human SHIP, the 145-kD inositol 5-phosphatase that associates with SHC after cytokine stimulation. Blood 88:2833-2840.

Yoshii K, Yu L, Mayne KM, Davidson N, Lester HA (1987) Equilibrium properties of mouse-Torpedo acetylcholine receptor hybrids expressed in Xenopus oocytes. J Gen Physiol 90:553-573.

Yu L, Leonard RJ, Davidson N, Lester HA (1991) Single-channel properties of mouse-Torpedo acetylcholine receptor hybrids expressed in Xenopus oocytes. Brain Res Mol Brain Res 10:203-211.

Yu XM, Askalan R, Keil II GJ, Salter MW (1997) NMDA channel regulation by channel-associated protein tyrosine kinase Src. Science 275:674-678.

Zaninetti M, Blanchet C, Tribollet E, Bertrand D, Raggenbass M (2000) Magnocellular neurons of the rat supraoptic nucleus are endowed with functional nicotinic acetylcholine receptors. Neuroscience 95:319-323.

Zaninetti M, Tribollet E, Bertrand D, Raggenbass M (2002) Nicotinic cholinergic activation of magnocellular neurons of the hypothalamic paraventricular nucleus. Neuroscience 110:287-299. 